\title{
A SUGGESTED REVISION OF THE CONTRACT DOCTRINE OF ANTICIPATORY REPUDIATION
}

\author{
"The duty to keep a contract at common law means a prodiclion \\ that you must pay damages if you do not kcep it-and nothing \\ else."

$$
\text { -Oliver IVendell Holmes" }
$$

A CONTRACT, by definition, requires a promise of future performance by at least one party. ${ }^{1}$ The promisee relies on the other party's promised performance. He may enter into additional contracts or incur further expenses in expectation of such performance. It is primarily for this right to rely that parties contract $;^{2}$ otherwise, barter or cash sales, rather than an exchange of promises, would suffice.

The basic purpose of a contract is therefore destroyed when one party to the contract notifies his promisee that he will not perform. ${ }^{3}$ Instead of the bargained-for ability to rely, the promisee has only a lawsuit against the repudiator. ${ }^{4}$ Recognizing this fact, all jurisdictions, but one, allow an immediate action for anticipatory repudiation ${ }^{\bar{J}}$ of certain contracts. ${ }^{0}$ An anticipatory

*Holates, Collected Legal Papers 175 (1920).

1. 1 Corbin, Contracts $\$ \$ 3-4$ (1950); 1 Williston, Contructs $\$ 1$ (rev. ed. 1936).

2. "A promise is a verbal act designed as a reliance to the promisee, and so as a means to the forecast of his own conduct." L. Hand, J., in Equitable Trust Co. of N.Y. v. Western Pacific Ry., 244 Fed. 485, 502 (S.D.N.Y. 1917), aff'd, 250 Fed. 327 (2d Cir.), cerl. dericd, 246 U.S. 672 (1918). See also Central Trust Co. v. Chicago Auditorium Ass'n, 240 U.S. 581 (1916) ; Hicks, Value and Capital 124, 135 (1939); Llewellyn, What Price Cortract?, 40 YALE L.J. 704, 717 (1931).

3. 5 CORBIn, Contracts 262 (1951). This destruction of purpose is most obvious where the injured buyer is in effect a middleman, purchasing only to resell at a profit. Sce, c.g., Wheeler v. New Brunswick \& Canada R.R., 115 U.S. 29 (1885), affirming 12 Fed. 377 (D. Conn. 1882).

4. 5 Corbin, Contracts 262 (1951) ; Uniform Commercial Code $\S 2-609$, comment 1 (1952).

5. 5 Wulliston, Contracts $\S 1314$ (rev. ed. 1937). The two leading cases on anticipatory repudiation are Hochster v. De La Tour, 2 E. \& B. 678, 118 Eng. Rep. 922 (1853), and Roehm v. Horst, 178 U.S. 1 (1900).

North Dakota and Nebraska initially rejected the anticipatory repudiation doctrine; but they now accept it. See Stanford v. AfcGill, 6 N.D. 536, 72 N.W. 938 (1897), ocerruled, Hart-Parr Co. v. Finley, 31 N.D. 130, 153 N.W. 137 (1915); Carstens v. MreDonald, 38 Neb. 858, 57 N.W. 757 (1894), ozerniled, Lang v. Todd, 148 Neb. 726, 28 N.W.2d 434 (1947).

Massachusetts is the sole hold-out against the anticipatory repudiation doctrine. Danicls v. Newton, 114 MIass. 530 (1874) ; P. P. Emory Mfg. Co. v. Salomon, 178 Mass. 582, 60 N.E. 377 (1901). However, upon repudiation, Massachusetts allows the injured party to rescind and obtain restitution. Johnson v. Starr, 321 Mass. 566, 74 N.E.2d 137 (1947). And where the repudiation is joined with a present refusal to perform, he may recover future damages. See, e.g., Garfield \& Proctor Coal Co. v. New York, N.H. \& H.R.R., 248 Irass. 502, 143 N.E. 312 (1924). See also Centennial Electric Co. v. Mrorse, 227 Mass. 485,116 
repudiation occurs when, prior to the promised date of performance, the promisor absolutely repudiates the contract. ${ }^{7}$ If the jurisdiction recognizes the anticipatory repudiation doctrine with respect to the contract involved, under present case law the injured promisee may: 1) rescind the contract and ste for restitution ; 2) treat the repudiation as a present breach ${ }^{8}$ and immediately sue for damages; or 3 ) disregard the repudiation and await the performance date. $^{9}$ If the last alternative is elected, the contract remains bincling on both parties; and the repudiator may withdraw his repudiation and perform as if there had been no repudiation. ${ }^{10}$ Also, any defenses arising subsequent to the repudiation are then available to the repudiating party. 11 'Thus, the doctrine does not recognize breach of a contract before performance date unless both parties agree.

N.E. 901 (1917). For a recent discussion of Massachusetts' refusal to accept the anticipatory repudiation doctrine, see Note, 31 B.U.L. Rev. 505 (1951).

6. For a discussion of the disagreement among jurisdictions on the question of which contracts fall within the anticipatory repudiation doctrine, see "Executory Limitation," p. 87 infra.

7. This Comment will not attempt to discuss what evidentiary facts are required to prove a repudiation. Its scope is limited to the treatment of an anticipatory repudiation once it is found to exist.

For a general definition of what constitutes an anticipatory repudiation, see RestaTEMENT, CoNTRACTS $\S 318$ (1932). The occurrence of a repudiation is a jury question. Hebron Mfg. Co. v. Powell Knitting Co., 171 Fed. 817 (3d Cir. 1909). For examples of the problems involved in proving an absolute repudiation, see Smoot's Case, 82 U.S. (15 Wall.) 36 (1872); Listman Mill Co. v. Dufresne, 111 Me. 104, 88 Atl. 354 (1913); Miller \& Sons Bakery Co. v. Selikowitz, 4 N.J. Super. 97, 66 A.2d 441 (1949).

8. The injured party may treat the repudiation as a present breach by bringing suit, acting in reliance on the repudiation, or simply notifying the repudiator of his acceptance of the repudiation. Barnebey v. Barron G. Collier, Inc., 65 F.2d 864 (8th Cir. 1933) (acceptance by bringing suit) ; Bisbee Linseed Corp. v. Paragon Paint \& Varnish Corp., 96 F.2d 464 (2d Cir. 1938) (acceptance by recontracting) ; McNeff v. White Eagle Brewing Co., 294 Ill. App. 37, 13 N.E.2d 493 (1938) (acceptance by letter).

9. See, e.g., Roehm v. Horst, 178 U.S. 1 (1900) ; Reliance Cooperage Corp. v. Trcat, 195 F.2d 977 (8th Cir. 1952) ; Carvage v. Stowell, 115 Vt. 187, 55 A.2d 188 (1947); Black \& Yates v. Negros-Philippine Lumber Co., 32 Wyo. 248, 231 Pac. 398 (1924).

Specific performance may also be granted in an anticipatory repudiation action if the equity requirements are met. Dixon v. Anderson, 252 Fed. 694 (4th Cir. 1918); Phez Co. v. Salem Fruit Union, 103 Ore. 514, 201 Pac. 222 (1921). Contra: Crosby v. Georgia Realty Co., 138 Ga. 746, 76 S.E. 38 (1912).

10. See, e.g., Wheeler v. New Brunswick \& Canada R.R., 12 Fed. 377 (D. Conn. 1882), aff'd, 115 U.S. 29 (1885) ; Southern Saw Mill Co. v. Herzfield, 35 Ga. App. 206, 132 S.E. 264 (1926) ; Bernstein v. Meech, 130 N.Y. 354, 29 N.E. 255 (1891); Shamlian v. Waxmant, 80 Pa. Super. 73 (1922). See Vold, Withdrazeal of Repudiation After Aulicipatory Brcach of Contract, 5 Texas L. Rev. 9 (1926).

11. See, e.g., Landes v. Klopstock, 252 Fed. 89 (2d Cir.), cert. denicd, 248 U.S. 570 (1918); Inman, Akers \& Inman v. Elk Cotton Mills, 116 Tenn. 141, 92 S.W. 760 (1905); Black \& Yates v. Negros-Philippine Lumber Co., 32 Wyo. 248, 231 Pac. 398 (1924). And if the injured party declines to accept the repudiation and then himself breaches the contract, the repudiator may recover damages. Central Lumber Co. v. Arkansas Valley Lumber Co., 86 Kan. 131, 119 Pac. 321 (1911) ; Hadfield v. Colter, 188 App. Div. 563, 177 N.Y. Supp. 382 (1919). 


\section{EXECUTORY LiMITATION}

Although all anticipatory repudiation jurisdictions apply the doctrine to executory contracts for marriage, ${ }^{12}$ services, transportation, and sale or delivery of goods, ${ }^{13}$ some of them refuse to apply the doctrine to contracts where the promisee has fully performed. ${ }^{14}$ This limitation operates as follows: assume $S$ agrees to sell goods to $B$ with payment to be made ninety days after shipment; $S$ may sue immediately if the repudiation occurs prior to shipment; but no action will lie until the payment date if $B$ first obtains the goods and then repudiates. These courts reason that since the promisee has fully performed, he has nothing to do but await the promisor's performance at the specified date. Therefore, they state, a repudiation cannot affect him. ${ }^{15}$ To allow an immediate action would needlessly remake the contract by granting the promisee a damage remedy prior to the date he expected performance. ${ }^{10}$ Yet if the injured party has not fully executed his contractual obligations, this view permits an anticipatory repudiation action because it would be unfair, after one party has repudiated, to require the other to act under the contract. ${ }^{17}$

12. Of course, an action for anticipatory repudiation of a promise to marry is permitted only where the breach of promise suit has not been abolished. For a compilation of the states which have eliminated this action, see Harper, Problears of TRE. F.MIILY 16S-9 (1952). For an example of an action for anticipatory repudiation of a marriage contract, see Holloway v. Griffth, 32 Iowa 409 (1871). And see HARPER, op. cit. supra at $165-7$ for a discussion of the measure of damage for breach of promise.

13. For statements of the general applicability of the anticipatory repudiation doctrine, see Roehm v. Horst, 178 U.S. 1 (1900) ; Moore v. Security Trust \& Life Ins. Co., 1GS Fed. 496, 503 (Sth Cir. 1909), cert. denicd, 219 U.S. 583 (1910); Kelly v. Security Mfutual Life Ins. Co., 186 N.Y. 16, 19, 78 N.E. 584, 585 (1906) ; Vold, Repudiation of Contracts, 5 Nes. L. BuLL. 269, 289 (1927).

14. N.Y. Life Ins. Co. v. Viglas, 297 U.S. 672 (1936) (alternate holding); Brown Paper Mill Co. v. Irvin, 146 F.2d 232 (Sth Cir. 1944) ; Brimmer v. Union Oil Co., 81 F.2d 437 (10th Cir.), cert. denied, 298 U.S. 668 (1936) ; Mobley v. New York Life Ins. Co., 74 F.2d 588 (5th Cir.), aff'd on other grounds, 295 U.S. 632 (1935); Hines v. Fidelity MIutual Life Ins. Co., 6 F. Supp. 692 (E.D.N.Y. 1934) ; Manufacturers' Furniture Co. v. Cantrell, 172 Ark. 642, 290 S.W. 353 (1927); Cobb v. Pacific Mlutual Life Ins. Co., 4 Cal. 2d 565, 51 P.2d 84 (1935) ; Kroch v. B.G. Operating Co., 286 IIl. App. 301, 308-09, 3 N.E.2d 285 (1936) ; Mabery v. Western Casualty \& Surety Co., $173 \mathrm{Kan} .586,250$ P.2d $\$ 24$ (1952); Huffman v. Martin, $226 \mathrm{Ky} .137,10$ S.W.2d 636 (192S) ; Rishmiller v. Prudential Ins. Co., 192 Minn. 348, 256 N.W. 187 (1934); Allen v. National Life \& Accident Ins. Co., 228 Mo. App. 450, 67 S.W.2d 534 (1937) ; Kelley v. Security Mfutual Life Ins. Co., 186 N.Y. 16, 78 N.E. 584 (1906) semble. See Roehm v. Horst, 178 U.S. 1, 18 (1900); King Features Syndicate v. Valley Broadcasting Co., 42 F. Supp. 107, 108 (N.D. Tex. 1941), aff'd, 133 F.2d 127 (5th Cir. 1943); Sagamore Corp. v. Willcut, 120 Conn. 315, 318, 180 Atl. 464, 465, (1935).

For a criticism of this executory limitation, see Note, 4 OKLA. L. REv. 112 (1951).

15. See, e.g., Parks v. Maryland Casualty Co., 59 F.2d 736 (W.D. Mo. 1932).

16. See Washington County v. Williams, 111 Fed. $\$ 01$ (Sth Cir. 1901) ; Mlanufacturers" Furniture Co. v. Cantrell, 172 Ark. 642, 290 S.W. 353 (1927); Aetna Life Ins. Co. v. Dorman, 51 Ga. App. 393, 180 S.E. 640 (1935).

17. See Roehm v. Horst, 178 U.S. 1, 19 (1900) ; Parks v. Mraryland Casualty Co., 59 F.2d 736 (W.D. Mo. 1932). 
This "executory limitation" often requires inequitable results. Thus, a creditor cannot recover from a repudiating debtor until the debt matures. ${ }^{18}$ Furthermore, the debtor's sale of all his property, and his preparations to leave the jurisdiction, do not alter this prohibition. ${ }^{10}$ The creditor must await failure to perform at the promised time before he may sue, although a successful action at that time may be insuperably difficult. ${ }^{20}$ Strict adherence to this executory limitation also requires an appellate court to reverse a trial court's award of payments not yet due, even though they had already accrued at the appeal decision date. ${ }^{21}$

Many courts which recognize the executory limitation in theory attempt to evade it where it would require injustice. These courts often label the repudiition a material breach of contract. ${ }^{22}$ Since a material breach is a present breach, this removes the case from the purview of the anticipatory repudiation doctrine. Thus by manipulating labels-anticipatory repudiation vs. present material breach-courts can govern the applicability of the executory limitation. But they can do this only where the promisor joins his repudiation with a failure to perform one of several installments. This combination is considered a mitterial breach of all further installments. And though these installments represent promises of future performance, ${ }^{23}$ immediate suit for all clamages is then permitted. $^{24}$

18. Washington County v. William, 111 Fed. 801, 810-11 (8th Cir. 1901); Upham v. Shattuck, 151 Kan. 966, 101 P.2d 901. (1940); Huffman v. Martin, 226 Ky. 137, 10 S.W.2d 636 (1928).

19. Moore v. Security Trust Co., 168 Fed. 496 (8th Cir. 1909), ccrt. denicd, 219 U.S. 583 (1910) (corporate dissolution); Kroch v. B.G. Operating Co., 286 111. App. 301, 3 N.E.2d 285 (1936) (receivership); Upham v. Shattuck, 151 Kan. 966, 101 P.2d 901 (1940) (insolvency through conveyance of assets); Huffman v. Martin, $226 \mathrm{Ky} .137,10 \mathrm{~S} . \mathrm{W} .2 \mathrm{~d}$ 636 (1928) (sale of assets and departure from jurisdiction).

20. See cases cited note 19 supra. See also Indian River Islands Corp. v. Manufacturers' Trust Co., 253 App. Div. 549, 2 N.Y.S.2d 860 (1st Dep't 1938) (mortgagor could generally withdraw property from mortgage so long as he met payments; allowed to do so even though he had repudiated).

21. Leon v. Barnsdall Zinc Co., 309 Mo. 276, 274 S.W. 699 (1925); cf. Crosby v. Georgia Realty Co., 138 Ga. 746, 76 S.E. 38 (1912).

22. See, e.g., Viglas v. N.Y. Life Ins. Co., 78 F.2d 829, 832 (1st Cir. 1935). rcv'd, 297 U.S. 672 (1936) ; Sagamore Corp. v. Willcutt, 120 Conn. 315, 180 Atl. 464 (1935) ; Hodges v. Blythe, 69 Okla. 163, 171 Pac. 16 (1918). This "material breach" label is also used in Massachusetts to permit an immediate action. Centennial Electric Co. v. Morse, 227 Mass. 486, 116 N.E. 901 (1917).

23. The technique of calling an anticipatory repudiation a present breach if it is accompanied by a present refusal to perform has been severely criticized. See Roehm v. Horst, 178 U.S. 1, 19 (1900) : "What reasonable distinction per se is there between liability for a refusal to perform future acts to be done under a contract in course of performance and liability for a refusal to perform the whole contract made before the time for commencement of performance." See also United Press Ass'n v. National Newspaper Ass'n, 237 Fed. 547, 553 (8th Cir. 1916). And many courts, without discussing the rationale, correctly label a repudiation which occurs after performance has begun, but prior to completion, an anticipatory repudiation. See, e.g., Bisbee Linseed Corp. v. Paragon Paint \& Varnish Corp., 96 
Discovering de minimis acts yet to be performed by the injured party is another technique used to avoid application of the executory limitation. Thus, an action for anticipatory repudiation of a disability insurance contract has been permitted where the plaintiff-insured was required to furnish a monthly physical report. ${ }^{25}$ And another court discovered that plaintiff might be required to "cooperate" with defendant's executor in determining what part of defendant's property equalled the sum promised to the plaintiff."

Without resort to such artificiality, a minority of courts which accept the executory limitation simply will not apply it when irreparable harm will result. ${ }^{27}$ Thus, an action for anticipatory repudiation has been permitted on a life insurance policy, ${ }^{28}$ but not on a disability insurance policy $;^{20}$ for the validity of the latter can be tested by suing for one installment, while refusal to apply the anticipatory repudiation doctrine to a life insurance situation would require awaiting the death of the insured. ${ }^{30}$ Courts also have permitted an action for

F.2d 464 (2d Cir. 1938) ; Continental Cotton Co. v. Mfann, 117 Misc. 280, 192 X.Y. Supp. 193 (City Ct. 1921) ; Benedict v. Harris, 158 Ore 613, 77 P.2d 442 (1938). The irrationality of this manipulation of labels is apparent in the employment contract example on 1.115 infra. Furthermore, labelling an anticipatory repudiation a present breach has caused needless problems to the injured party. See, c.g., text at notes $162-5$ infra.

Professor Williston, however, argues that a repudiation of future performance is correctly labelled a present breach when it is accompanied by a present failure to perfurm. 5 Wiliston, Contracts $\$ 1317$ (rev. ed. 1937).

24. See cases cited note 22 supra.

25. Federal Life Ins. Co. v. Rascoe, 12 F.2d 693 (6th Cir. 1926). But other courts have refused to make such a finding in order to avoid the executory limitation. Kithcart v. Metropolitan Life Ins. Co., 1 F. Supp. 719 (W.D. Mfo. 1932) ; Rishmiller v. Prudential Ins. Co., 192 Minn. 348, 256 N.W. 187 (1934); Allen v. National Life \& Accident Ins. Co., 228 Mo. App. 450, 67 S.W.2d 534 (1937).

26. Pollack v. Pollack, 46 S.W.2d 292 (Tex. Com. App. 1932). See also Equitable Trust Co. v. Western Pacific Ry., 244 Fed. 485, 501 (S.D.N.Y. 1917), aff'd, 250 Fed. 327 (2d Cir. 1918).

27. Central Trust Co. v. Chicago Auditorium Ass'n, 240 U.S. 581 (1916) (bankruptcy of repudiator) ; United States v. Harris, 100 F.2d 268 (9th Cir. 1938) (same); Guitron v. Rodriguez, 105 Cal. App. 513, 288 Pac 134 (1930) (execution sale of repudiator's property) ; Crabtree v. MIessersmith, 19 Iowa 179 (1865) (departure from jurisdiction); Internal Water Heater Co. v. Burns Bros., 114 N.J.L. 368, 176 Atl. 380 (1935) (repudiator assigned property involved to third party); Casey v. Miurphy, 143 Wash. 17, 253 Pac. 1078 (1927) (court ignored executory limitation, possibly because senseless to compel a resuit).

Cf. Cardozo, J., in N.Y. Life Ins. Co. v. Viglas 297 U.S. 672, 682 (1936) : "acederation of future benefits [is permitted where] essential to the attainment of present reparation."

28. See life insurance cases cited note 159 infra.

29. See disability insurance cases cited note 150 infra.

30. Compare Wollman v. Brotherhood of American Yoemen, 231 Mo. App. 36, 95 S.W.2d 645 (1936), with Allen v. National Life \& Accident Ins. Co., 228 Mo. Anp. 450, 67 S.W.2d 534 (1934); and compare American Ins. Union v. Woodward, 118 Olila. 248, 247 Pac. 398 (1926), with Mfid-Continent Life Ins. Co. v. Christian, 164 Okla. 161, 23 P.2d 672 (1932). See discussion in Mobley v. New York Life Ins. Co., 74 F.2d 588,590 (5th Cir.), aff'd on other grounds, 295 U.S. 632 (1935). 
anticipatory repudiation of a promise solely for the payment of money in installments $;^{31}$ it would be inequitable to require the injured party either to stre for each installment or to wait until all are due. But where performance of the repudiating party, or computation of damages, is contingent upon a future occurrence, the same courts revert to the executory limitation $; 32$ while it might be unfair to both parties to require numerous suits, these courts reason that it would be more unjust to allow an immediate action since the damages are too uncertain to compute.

Finally, many jurisdictions totally reject the executory linitation as unsound. ${ }^{33}$ This is the correct view; a promisee who has fully performed should not be refused an immediate damage remedy. No court applies the executory limitation when the same fully-performed promisee, following an anticipatory repudiation, brings an action for rescission and restitution. ${ }^{34}$ Yet, this grants him a remedy prior to the promised date of performance. And, in fact, the court similarly remakes a contract whenever it permits an anticipatory repudiation recovery; for a promisee may then be able to obtain the consideration for which he bargained, in the form of court-ordered damages, prior to the date he expected performance.

The unreasonableness of the executory limitation is further demonstrated by the result obtained. A promisee who has yet done nothing is placed in a better position than one who has already performed; the former obtains his remedy prior to the performance date, while the promisee who has completely

31. Central Trust Co. v. Chicago Auditorium Ass'n, 240 U.S. 581 (1916) ; Pierce v. Tennessee Coal, I. \& R.R., 173 U.S. 1 (1898) ; United States v. Harris, 100 F.2d 268 (9th Cir. 1938) ; Guitron v. Rodriguez, 105 Cal. App. 513, 288 Pac. 134 (1930); Spencer v. Kansas Casualty \& Surety Co., 116 Kan. 491, 227 Pac. 357 (1924) ; Internal Water Heater Co. v. Burns Bros., 114 N.J.L. 368, 176 Atl. 380 (1935) ; Casey v. Murphy, 143 Wash. 17, 253 Pac. 1078 (1927). See Aetna Life Ins. Co. v. Dorman, 51 Ga. App. 393, 395, 180 S.E. $640,641(1935)$.

32. Compare Central Trust Co. v. Chicago Auditorium Ass'n, 240 U.S. 581 (1916), with United States v. Worley, 281 U.S. 339 (1930); and compare Spencer v. Kansas Casualty \& Surety Co., 116 Kan. 491, 227 Pac. 357 (1924), with Mabery v. Western Casualty \& Surety Co., 173 Kan. 586, 250 P.2d 824 (1952). See King Features Syndicate v, Valley Broadcasting Co., 42 F. Supp. 107, 108 (N.D. Tex. 1941), aff'd, 133 F.2d 127 (5th Cir. 1943).

33. Equitable Trust Co. v. Western Pacific Ry., 244 Fed. 485, 501 (S.D.N.Y. 1917), aff'd, 250 Fed. 327 (2d Cir.), cert. denied, 246 U.S. 672 (1918) ; Universal Life \& Accident Ins. Co. v. Sanders, 129 Tex. 344, 102 S.W.2d 405 (1937). At times, courts have, without discussing the question, allowed an action for anticipatory repudiation of a contract which would normally fall within the executory limitation. See Central Trust Co. v. Chicago Auditorium Ass'n, 240 U.S. 581 (1916); United States v. Harris, 100 F.2d 268 (9th Cir. 1938); Guitron v. Rodriguez. 105 Cal. App. 513, 288 Pac. 134 (1930); Internal Water Heater Co. v. Burns Bros., 114 N.J.L. 368, 176 Atl. 380 (1935).

34. See, e.g., Caramini v. Tegulias, 121 Conn. 548, 186 Atl. 482 (1936) ; Petschke v. Rohdiek, 173 N.Y. Supp. 380 (App. Term. ist Dep't 1919). Massachusetts, which does not accept the anticipatory repudiation doctrine, permits an action for rescission upon a repudiation prior to the performance date. Johnson v. Starr, 321 Mass. 566, 74 N.E.2d 137 (1.947). 
performed cannot use the anticipatory repudiation doctrine. ${ }^{35}$ Yet, for example, where the fully-performed promisee is a seller of goods, besides being unable to bring an immediate action, he no longer has the goods; therefore he cannot even secure part of the promised consideration by reselling on the market. The anticipatory repudiation doctrine should not be so limited. ${ }^{30}$

With the exception of this executory limitation, courts agree in theory on the operation of the anticipatory repudiation doctrine. Verbally, the plaintiff's option to accept or reject the repudiation is adopted as basic. In practice, however, this option is often illusory because the injured party is sometimes required to accept the repudiation. Furthermore, no matter what course of action the injured party elects, there is not even theoretical agreement on the method of computing damages in an action for anticipatory repudiation. While all courts purport to award that amount which will place the injured party in as good a position as if the contract had been performed, ${ }^{37}$ present case law is in hopeless confusion as to the correct just compensation method. The only fruitful analysis of the cases can be obtained by grouping them according to subject matter: Sales, Unfinished Goods, Insurance, Employment, and Leases.

\section{Sales Contracts}

The general rule for computing damages for breach of an executory contract of purchase and sale grants the injured party the difference between con-

35. Sce Moore v. Security Trust \& Life Ins. Co., 168 Fed. 496, 505 (Sth Cir. 1909) (dissenting opinion): "I perceive no reason for believing that the plaintifis, by" reason of having performed their part of the contract, [should be] in a less favorable pusition than if the contract [were] still executory as to them."

36. See Pollack v. Pollack, 46 S.W.2d 292, 293 (Tex. Comm. App. 1932) : "[T]here is [no] logical reason that can be given for [the anticipatory repudiation doctrine's] application to contracts still to be performed on both sides that does not apply with equal force to those which are fully performed on one side."

UNIFORN CONIIIERCIAL CODE $\$ 2-610$ 's effect on the executory limitation is not clear. Professor Williston claims that this section abolishes the executory limitation. Williston, The Law of Sales in the Proposed UCC, 63 Hanv. L. Rev. 561, 584 (1950). However, other analyses maintain that no change is made by the UCC. See CALrF. Cossar. ox UNiforar State Laws, Annotations to the Proposed UCC 28 (1952); Report of Pe:s:. Gen. Assearbly Subcomar. on the Proposed UCC 45 (1952); Texis Legislative Cul:CII, ANaliysis of ARTICIE 2 of THE UCC 205 (1953).

Both interpretations are possible. The section does not specifically limit its appliability to contracts where the injured party has not completed performance. On the other hand, it does state that it applies only to contracts where the repudiated performance will cause a loss which "will substantially impair the value of the contract." And according to present executory limitation case law, a repudiation where the innocent party has fully performed does not injure him. See cases cited note 15 stpra and accompanying text. And sce Grand Lodge Brotherhood of R.R. Trainmen v. Afartin, 218 S.W. 40, 41 (Tex. Civ. App. 1919). This rationale could be used under the UCC to continue the executory limitation.

37. 5 Corbin, Contracts $\S 992$ (1951); 5 Wuurston, Contracts $\S 133 \$$ (rev. ed. 1937). 
tract price and market price on the date on which performance was due.38 Thus, computation is simple when the guilty party does not, prior to the performance date, notify the other party of his refusal to perform. Upon failure to receive performance, the innocent party may repurchase or resell on the market. ${ }^{39}$ And the breaching party is charged for any loss.

But where there is a repudiation prior to the performance date, alternative methods of computation are apparent. Since the promised performance date remains unaltered in the contract, damages could still be computed as of that date. On the other hand, under the anticipatory repudiation doctrine, the innocent party has the option of treating the repudiation as a breach; if he elects to treat it as such, damages could rationally be computed as of that date. Furthermore, the rule of avoidable consequences, which imposes a duty on the injured party to minimize damages, could be held applicable; then clamages would be computed as of the repudiation, acceptance of repudiation, or performance date, depending on which date results in the least clamages.

\section{Computation Where the Injured Party Disregards the Repudiation}

If the injured party disregards the repudiation and insists upon performance, most courts compute damages as of the date of performance. ${ }^{40}$ For in

38. McCormack, Damages $658-9$ (1935). If there is no market for the goods, the injured seller may recover the contract price less the value of the goods to the seller; often, because only salvage value remains, this recovery is close to the contract price. Sce, e.g., Solomon v. Waterbury Brass Goods Corp., 6 F.2d 990 (2d Cir. 1925). The injurcd buyer may recover the difference between the contract price and what it costs to abtain a suitable substitute. Vulcan Iron Works Co. v. Roquemore, 175 Fed. 11 (5th Cir. 1909). If this is impossible, the damages will be the difference between contract price and the value of the goods to the buyer. Weed v. Lyons Petroleum Co., 294 Fed. 725734 (D. Del. 1923), aff'd, 300 Fed. 1005 (3d Cir. 1924). This includes consequential damages. Ehrenworth v. George F. Stuhmer \& Co., 229 N.Y. 210, 128 N.E. 108 (1920).

39. Farish Co. v. Madison Distributing Co., 37 F.2d 455 (2d Cir. 1930). In that decision, Judge Learned Hand concluded that damages should be computed on plaintiff's recontract if he proceeded diligently to recontract in the readily available marliet. In order to compute damages on the basis of a recontract, this recontract need not be made precisely on the theoretical date of damage computation. For example, a recontract within a reasonable time after the performance date, when damages are computed as of the performance date, is permitted. Gussman v. Byrd Cattle Co., 11 F.2d 136 (5th Cir. 1926). But too long a delay will make the recontract unreasonable; the damages will then be computed on the market-contract difference on the performance date. California Sugar \& White Pine Co. v. Whitmer Jackson \& Co., 33 N.M. 117, 263 Pac. 504 (1928). And the injured party may use a market other than the place of delivery if there is not a readily available market there. Ibid.

There is disagreement over whether the injured party must accept a new offer from his repudiator. Compare Krebs Hop Co. v. Livesley, 59 Ore. 574, 114 Pac. 944, aff'd on rehearing, 118 Pac. 165 (1911), with Key v. Kingwood Oil Co., 110 Okia. 178, 236 Pac. 598 (1925).

Throughout this comment, the statement that damages are computed as of a certain date gives only the theoretical date for computation. In actuality, the injured party would always be permitted to prove, and compute damages on, a recontract made other than on the computation date, if it is reasonably close to the theoretical date.

40. Reliance Cooperage Corp. v. Treat, 195 F.2d 977 (8th Cir. 1952); Compania 
this case the repudiation is not treated as a breach. A small minority of courts modifies this rule: if less damages would have been incurred by recontracting on the repudiation date, damages are computed as of that date; otherwise, the performance date is used. ${ }^{41}$

Most courts rightly reject this duty to mitigate when the injured party does not accept the repudiation. ${ }^{42}$ Such a duty compels the injured party to be a crystal-gazer, speculating at his own risk, solely for the benefit of the guilty party. A simple example illustrates the injustice of the mitigation rule in this case: ${ }^{43} B$ contracts to buy a quantity of rice from $S$, at 10 e per pound at a specified future date. $B$ repudiates prior to the performance date when the market price is $8 \mathrm{c}$. $S$ rejects the repudiation and awaits the performance date. At that time, $S$ resells on the market for $6 \mathrm{r} / 2 \mathrm{c}$. $S^{\prime} \mathrm{s}$ loss on the resale is $3 \mathrm{~J} / 2 \mathrm{c}$ per pound. If $S$ had resold at the repudiation date, his loss would have been only $2 c$ per pound. Since less damage would have been incurred on a repudia-

Engraw Com'l E. Ind. v. Schenley Distillers Corp., 181 F.2d $\$ 76$ (9th Cir. 1950); Callan v. Andrews, 48 F.2d 118 (2d Cir. 1931); Vogt Bros. Mfg. Co. v. Sloss-Sheffield Steel \& Iron Co., 297 Fed. 54 (6th Cir. 1924) ; Second National Bank of Hobolien v. Columbia Trust Co., 288 Fed. 17 (3d Cir. 1923); Continental Grain Co. v. Simpson Feed Co., 102 F. Supp. 354 (E.D. Ark. 1951) ; Joseph Denunzio Fruit Co. v. Crane, 79 F. Supp. 117 (S.D. Cal. 1948), aff'd, 188 F.2d 569 (9th Cir. 1951); Armstrong v. Walters, 223 Fed. 451 (E.D. Pa. 1915) ; Belisle v. Berkshire Ice Co., 98 Conn. 689, 120 Atl. 599 (1923); Mendel v. Converse, 30 Ga. App. 549, 118 S.E. 586 (1923); Kadish v. Young, 108 Ill. 170 (1883); York-Draper Mercantile Co. v. Lusk, 6 Kan. App. 629, 49 Pac. 788 (1897); Bemis Bros. Bag Co. v. Farmers' Supply Co., 19 La. App. 285, 140 So. 73 (1932); Austrian \& Co. v. Springer, 94 Mich. 343, 54 N.W. 50 (1S92); Fahey v. Updike Elevator Co., 102 Neb. 249, 166 N.W. 622 (1918); California Sugar \& White Pine Co. v. Whitman Jackson \& Co., 33 N.M. 117, 263 Pac. 504 (1928) ; Krebs Hop Co. v. Livesley, 59 Ore. 574, 114 Pac. 24, aff'd on rehearing, 59 Ore. 574, 118 Pac. 165 (1911) ; Rees v. Bowers Co., 280 Pa 474, 124 Atl. 653 (1924) ; Hooper v. Bell, 210 S.IW.2d 870 (Tex. Civ. App. 1948) ; Sloss-Sheffield Steel \& Iron Co. v. Wisconsin Foundry \& Miachine Co., 187 Wis. 34, 203 N.W. 746 (1925).

41. W. H. Edgar \& Son v. Grocers' Wholesale Co., 298 Fed. 878 (Sth Cir. 1924); Crane Iron Works v. Cox \& Sons, 28 F.2d 32S (3d Cir. 1928); West v. Pritchard, 19 Conn. 212 (1848); Long v. Conklin, 75 Ill. 32 (1874); York-Draper Mlercantile Co. v. Lusk, 45 Kan. 182, 25 Pac. 646 (1891); Goldsmith v. Stiglitz, 228 Mich. 255, 200 N.WV. 252 (1924).

There are scattered holdings requiring computation as of the repudiation date whether or not it will mitigate damages. Friedman Iron \& Supply Co. v. Beaird Co., 222 La. 627 , 63 So. 2d 114 (1952); Listman Mill Co. v. Dufresne, 111 Mfe. 104, 8s Atl. 354 (1913); Allen v. Wolf River Lumber Co., 169 Wis. 253, 172 N.W. 158 (1919); of. Rhodes v. Cleveland Rolling Mill Co., 17 Fed 426 (C.C.N.D. Ill. 1883), reid on olher grousds, 121 Fed. 255 (C.C.N.D. I11. 1887).

42. See Reliance Cooperage Corp. v. Treat, 195 F.2d 977 (Sth Cir. 1952) ; Callan v. Andrews, 48 F.2d 118 (2d Cir. 1931); Second National Bank of Hoboken v. Columbia Trust Co., 288 Fed. 17 (3d Cir. 1923); Joseph Denunzio Fruit Co. v. Crane, 79 F. Supp. 117 (S.D. Cal. 1948), aff'd, 188 F.2d 569 (9th Cir. 1951); Kadish v. Young, 108 Ill. 170 (1883); Kansas Flour Mills Co. v. Brandt, $98 \mathrm{Kan} .587,158$ Pac. 1120 (1916). See also 5 Corbin, Contracts 263-5 (1951).

43. The facts of this example are those of Goldsmith v. Stiglitz, 228 Mich. 255, 200 N.W. 252 (1924). 
tion date resale, $S$ 's damages are computed as of that date. But an increase in the market price after the repudiation date would have required a different result. Suppose the market price on the performance date had risen to $9 \mathrm{c}$ per pound but that $S$ had resold at the repudiation date. $S$ 's damages would then be computed as of the performance date since the prior resale increased, rather than minimized, damages. ${ }^{44}$

Under a duty to mitigate, the injured party is thus compelled to guess the future course of a changing market, while the repudiator sits back and awaits the performance date. At that time, the guilty party would compare the market price on the repudiation date with that on the performance date. If computation as of the repudiation date creates less damages, he would defend against performance date recovery on the ground of a mitigation duty ${ }^{45}$ if otherwise, and the plaintiff had recontracted on the repudiation date, the defense that an injured party may not enhance damages would suffice to require computation as of the performance date. ${ }^{46}$ Hence, the guilty party can not lose.

Furthermore, any requirement that an injured party who has disregarded a repudiation must mitigate prior to the performance date is contrary to the anticipatory repudiation doctrine. ${ }^{47}$ So long as the doctrine permits an injured party to ignore a repudiation and insist upon performance, when he does so, damages should be computed as of the performance date. Otherwise, his option is substantially eliminated, since the duty to mitigate may require recontracting on the repudiation date. Moreover, if it be assumed that the injured party recontracts upon repudiation in order to fulfill his duty to mitigate, but does not wish thereby to accept the repudiation, ${ }^{48}$ the repudiator can still reinstate the contract by withdrawing his repudiation. ${ }^{40}$ If he does so, the injured party would be left with two contracts for the same goods! ${ }^{50}$

When the repudiation is disregarded, rejection of the mitigation duty does not unduly burden the repudiator; for he can always minimize his damages by

44. See, e.g., Rhodes v. Cleveland Rolling-Mill Co., 17 Fed. 426, 433-4 (C.C.N.D. Ill. 1883) (damages as of repudiaton date unless less damages as of performance datc).

45. See, e.g., ibid; Goldsmith v. Stiglitz, 228 Mich. 255, 200 N.W. 252 (1924).

46. See e.g., Rhodes v. Cleveland Rolling-Mill Co., 17 Fed. 426, $433-4$ (C.C.N.D. Ill. 1883), rez'd on other grounds, 121 Fed. 255 (C.C.N.D. Ill. 1887); Second National Banle of Hoboken v. Columbia Trust Co., 288 Fed. 17 (3d Cir. 1923).

47. Reliance Cooperage Corp. v. Treat, 195 F.2d 977 (8th Cir. 1952); Kadish v. Young, 108 Ill. 170 (1883).

48. Admittedly, this assumption is unrealistic, since a recontract constitutes acceptance of the repudiation. See note 8 supra. However, it helps to demonstrate the theoretical inconsistency.

49. See authorities cited note 10 supra.

50. See Reliance Cooperage Corp. y. Treat, 195 F.2d 977, 982 (8th Cir. 1952): "There is no justification for ruling that, after the plaintiff was advised that the defendant did not intend to perform, it must hold itself in readiness to accept performance from him and at the same time, at its own risk and expense, buy the staves contracted for upon the open market in the hope of reducing the defendant's liability for damages in case he persisted in his refusal to fulfill his obligations." And see Kadish v. Young, 108 Ill. 170 (1883). 
hedging. ${ }^{51}$ Assume $S$ contracts to sell 1000 bushels of wheat to $B$ for $\$ 1000$, delivery to be in six months. One month later, when the price of equivalent wheat is $\$ 1100, S$ repudiates. $B$ rejects the repudiation. $S$, believing that the market price of wheat will continue rising, wishes to have damages computed as of the repudiation date. He should first withdraw his repudiation. ${ }^{82}$ Then, by immediately contracting to purchase a similar quantity of wheat to be delivered to $B, S$ can limit his loss to the difference between contract price and market price on the repudiation date. ${ }^{53}$ Thus, the injured party is assured of obtaining performance of the contract. And the guilty party, if he correctly predicts the market, can avert additional damages.

\section{Computation Where the Injured Party Accepts the Repudiation}

Even though the injured party accepts the repudiation, a substantial number of courts still compute damages as of the performance date. ${ }^{\text {ti }}$ Although it has the support of most commentators, ${ }^{55}$ this method seems irrational. The anticipatory repudiation doctrine permits the innocent party to treat the repudiation as a breach; by such action he agrees to full destruction of the contract, except for recovery of damages. ${ }^{56}$ He can no longer expect performance, and the

51. See 5 CoReIn, ConTracts 265 (1951): "Let the repudiator use his own prophetic judgment, take the risks that are involved therein, and get the profit or suffer the loss that may be the result."

52. The repudiator may withdraw his repudiation at any time until it is accented by the injured party. See authorities cited note 10 supra.

53. $S$ will pay $\$ 1100$ for the wheat to be delivered to $B$. And he will receive \$1000 from $B . S$ 's loss is therefore only $\$ 100$, the contract-market difference on the repudiation date. Any subsequent rise in the market will be borne by the party who contracted to sell $S$ the wheat for $\$ 1100$. Yet, while $S$ is thereby able to limit his damages, $B$ will receive the performance for which he contracted.

54. In re Marshall's Garage, 63 F.2d 759 (2d Cir. 1933); Gentile Bros. v. Rose, 7 F.2d 879 (6th Cir. 1925) ; Second National Bank of Hobolen v. Columbia Trust Co., 288 Fed. 17 (3d Cir. 1923); Cherry Valley Iron Works v. Florence Iron River Co., 64 Fed. 569 (6th Cir. 1894) ; Missouri Furnace Co. v. Cochran, 8 Fed. 463 (W.D. Pa. 1881); Hart v. Marbury, 82 Fla. 317, S0 So. 173 (1921) ; Phosphate Mlining Co. v. Atlanta Oil \& Fertilizer Co., 20 Ga. App. 660, 93 S.E. 532 (1917); Delaware \& Hudson Canal Co. v. Mitchell, 92 Ill. App. 577 (1901) ; Bemis Bros. Bag Co. v. Farmers' Supply Ca., 19 La. App. 285, 140 So. 73 (1932) ; Simons v. Ypsilanti Paper Co., 77 Mfich. 185, 43 N.W. 864 (1889); Segall v. Finlay, 245 N.Y. 61, 156 N.E. 97 (1927); John Dimon Corp. v. Federal Sugar Refining Co., 215 App. Div. 140, 213 N.Y. Supp. 106 (1st Dep't 1925); Phez Co. v. Salem Fruit Union, 103 Ore. 514, 201 Pac. 222 (1921); Rees v. Bowers Co., $200 \mathrm{P}_{3}$ 474, 124 Atl. 653 (1924); Hopkins v. Le Cato, 142 Va. 769, 123 S.E. 55 (1925); Hill v. Chipman, 59 Wis. 211, 18 N.W. 160 (1884). See Churchill Grain \& Seed Co. v. Newtun, SS Conn. 130, 135, 89 At1. 1121, 1123 (1914); Davis v. Grand Rapids Schuol-Furniture Co., 41 W. Va. 717, 721, 24 S.E. 630,631 (1896).

55. See, e.g., 5 Corbin, Contracts $\$ 1053$ (1951); 5 Winuston, Co:trults $\$ 1383$ (rev. ed. 1937); Mayne, Damages 162-4 (10th ed. 1927); Restateure:t, Cosmacts $\S 338$ (1932) ; Beale, Damages Upon Repudiation of a Contract, 17 YuL L.J. 433 (1908); Corbin, Danages Upon Repudiation of a Contract, 17 YaLE L.J. 611 (1908); Vold, Kcpudiation of Contracts, 5 NEB. L. BuLI 269, 315 et seq. (1927) ; Note, 24 CoL L. Rar. 55 (1924); Note, 52 HaRv. L. REv. 817 (1939).

56. See text p. 86 supra. 
guilty party can no longer withdraw his repudiation. ${ }^{67}$ Yet, damages are computed as of the performance date.

Where the repudiation has been accepted, computing damages as of the performance date makes the entire doctrine nonsensical. Except where the injured party wishes to void the contract without incurring liability, t8 there is no reason for him to accept the repudiation under such a rule. Unless he, the injured party, wishes to speculate, he can not act in reliance on the repudiation by executing a new contract. ${ }^{59}$ For the defendant will be liable only for damages on the original contract as if there had been no repudiation, i.e., damages will be computed as of the performance date.

Of course, performance date computation may aid the plaintiff. He may abtain recovery for more loss than he actually incurred. Thus, in Segall v. Finlay, ${ }^{60}$ seller repudiated a contract for the sale of 4000 tons of sugar at the price of $\$ 410,000$. Buyer accepted the seller's repudiation when the market price for a similar contract was $\$ 460,400$; and apparently he recontracted at that price. ${ }^{61}$ Therefore, plaintiff's actual damage was $\$ 50,400$. Yet plaintiff's recovery was computed on the performance date price of a similar contract, which was $\$ 516,400$. The extra $\$ 56,000$ recovered was a windfall. However, it must be remembered that this plaintiff benefited only because he correctly guessed the market's fluctuations. True, without the repudiation, plaintiff conld have obtained the same extra profit by entering into an additional purchase contract on the date of the repudiation for resale on the performance date. But he un-

57. See text at note 10 supra.

58. Where a repudiation is received by a party who also desires to avoid the contract he need only accept the repudiation. All contractual duties are thereby destroyed. See cases cited note 10 supra. And since he is not the repudiator, he cannot be sucd for breaching the contract. Thus, e.g., in Hadfield v. Colter, 188 App. Div. 563, 177 N.Y. Supp. 382 (1st Dep't 1919), defendant would not have been found liable for damages had he accepted plaintiff's repudiation prior to the time it was withdrawn. Instead of so doing, defendant disregarded the repudiation. After plaintiff-repudiator reinstated the contract, defendant repudiated. And he was held liable for this repudiation.

59. For illustrations of the loss an injured party can incur by recontracting at a date prior to performance date, see Missouri Furnace Co. v. Cochran, 8 Fed. 463 (W.D. Pa. 1881) ; and Guaranty Trust Co. v. Meer, 114 Misc. 327, 187 N.Y. Supp. 288 (1921). In both cases, the injured party in apparent good faith recontracted upon receiving the repudiation. However, a sudden change in the market occurred so that a performance date computation yielded less damages than computation on the recontract. Therefore, the court chose the former measure and in each case, the injured party suffered a huge loss.

60. 245 N.Y. 61,156 N.E. 97 (1927).

61. Neither the opinion nor record of the case explicitly states that such a recontract was made. However, it is clear that Segall could have recontracted on the repudiation acceptance date; a sugar exchange where such contracts could easily be made was available to Segall. Transcript of Record, p. 109, Segall v. Finlay, 245 N.Y. 61, 156 N.E. 97 (1927). And since Segall had obligations to deliver the sugar to his purchaser, $i d$. at 47 , it seems without doubt that he would recontract upon repudiation.

It is interesting to note that Segall began negotiating for a recontract seven days before he formally accepted the repudiation, when the difference between contract and market was only $\$ 11,200$. He obtained a willing seller; yet he did not then conclude the recontract. Id. at 27 . 
doubtedly would have refrained from so doing had the defendant not repudiated. The new contract was executed solely to give plaintift the security he lost due to the defendant's repudiation. ${ }^{62}$ Yet, he received unexpected profits. ${ }^{23}$

Realizing these inequities of performance date damage computation, a sizable number of courts accept other alternatives. Mritigation by recontracting, if it will minimize damages, is required in some of these jurisdictions. of Similar consequences here obtain as those already discussed with respect to the mitigation duty when the repudiation is not accepted."

Another device used is "cover." This permits the injured party" to resell or repurchase on the market at any time after acceptance of the repudiation. ${ }^{67}$ The damages recoverable are then the difference between the contract price and the resale or repurchase price. This method produces certainty to the injured party. ${ }^{68}$ But there is still no security for the repudiator. A plaintiff may pick any intervening date between repudiation and performance to cover. Therefore, he may choose the date of the greatest damages as his cover date.

62. The contract between Segall and Finlay was not an "exchange" contract which is a speculative option to purchase and sell a certain amount of sugar at a statcd position. It was rather a "street market contract for future delivery" which is a cuntract covering an actual delivery of sugar. Id. at 59. Segall required the security of a recontract in order to be sure of fulfilling his obligation to his purchaser. Id. at 47 .

63. The only profit Segall expected when he entered into this contract was the difierence between the cost to him under this repudiated contract and the resale price. The court's damage computation gave him $\$ 56,000$ extra profit.

64. Cox \& Sons Co. v. Crane Iron Works, 5 F.2d 314 (3d Cir. 1925); Golden Cycle Mining Co. v. Rapson Coal Mfining Co., $18 S$ Fed. 179 (Sth Cir. 1911); Crown Products Co. v. California Food Products Corp., 77 Cal. App. 2d 543, 175 P.2d \$61 (1947); Mlendel v. Converse, $30 \mathrm{Ga}$. App. 549, 118 S.E. 586 (1923); Central Lumber Co. v. Artansas Valley Lumber Co., 86 Kan. 131, 119 Pac. 321 (1911); Goldsmith v. Stiglitz, 228 Mich. 255, 200 N.W. 252 (1924). See Delaware \& Hudson Canal Co. v. Mlitchell, 92 Ill. App. 577,582 (1901).

The duty to mitigate is sometimes confined to situations where the goods are regularly bought and sold for future delivery. The damages are then computed on the difference between the contract price and the market price for an equivalent contract. Sce Slicele Coal Co. v. Arnold, 200 Fed. 393 (2d Cir. 1912).

65. See notes $42-6$ supra and accompanying text. For criticism of this duty to mitigate, see cases cited note 42 supra. And see Restatenrent, Contracts $\$ 338$, illus. 3 (1932); Beale, Damages Upon Repudiation of a Contract, 17 YALE L.J. 443, 454-5 (1908) ; Corbin, Damages Upon Repudiation of a Contract, 17 YaLe L.J. 611 (190S); Note, 52 Hans. L. REv. 817,823 (1939).

66. "Cover" is any recontract made by and at the option of the injurcd party, in good faith, after a repudiation.

67. Donati v. Cleveland Grain Co., 221 Fed. 168 (4th Cir. 1915) ; Wendt v. Ismert= Hincke Milling Co., 107 Ark. 106, 154 S.W. 194 (1913); Neely v. Willard Bag \& .lfg. Co., 23 Ga. App. 598, 99 S.E. 167 (1919) ; James H. Rice Co. v. Penn. Plate Glass Co., 88 III. App. 407 (1900) ; Struthers-Ziegler Cooperage Co. v. Farmers' Manufacturing Co., 233 Mich. 298, 206 N.W. 331 (1925) ; Canadian Industrial Alcohol Co. v. Dunbar Alulasses Co., 258 N.Y. 194179 N.E. 383 (1932).

68. The injured party will then be assured of receiving the performance fur which he contracted, and at the same price. Any discrepancy in price between the original contract and the recontract will be recoverable in damages from the repudiator. 
But he need not announce his cover until trial. Thus, if plaintiff's business requires many such contracts, he may recontract at the lowest damage price during the intervening period and yet base his cover on a similar transaction made at the peak damage price. ${ }^{60}$

A few courts have permitted a limited right to cover. ${ }^{70}$ Damages are then computed on the cover price only if it results in less damages than would have resulted had the plaintiff not covered. But this, like the duty to mitigate, ${ }^{71}$ makes a speculator of the innocent plaintiff. If he covers, he does so only at his own risk, and solely for the defendant's benefit. ${ }^{22}$

Many courts adopt a fifth alternative for measuring damages-the date of repudiation acceptance. ${ }^{73}$ Since an injured party often accepts a repudiation

69. For illustrations of situations where the injured party was regularly executing contracts, any of which he could label his "cover" contract, see Bisbee Linseed Corp. v. Paragon Paint \& Varnish Corp., 96 F.2d 464 (2d Cir. 1938) ; Crane Iron Works v. Cox \& Sons, 28 F.2d 328 (3d Cir. 1928) ; Armstrong v. Walters, 223 Fed. 451 (E.D. Pa. 1915). In Bisbee Linseed, the injured seller also admitted that his resale price was below marlict on the date he recontracted. And in Armstrong, the court found that plaintiff repurchased on the peak damage date.

70. Morris v. Supplee, 208 Pa. 253, 57 Atl. 566 (1904) ; Goldfarb v. Campe Corp., 99 Misc. 475, 164 N.Y. Supp. 583 (City Ct. 1917).

71. See notes $42-6$ supra and accompanying text. And see note 65 supra.

Limited right to cover differs from a duty to mitigate only in that mitigation is recuired while limited cover is at the injured party's option.

72. See, e.g., Morris v. Supplee, 208 Pa. 253, 259-60, 57 Atl. 566, 568 (1904) : "though the buyer is not bound to supply himself before the contract date of delivery, . . ., yet he is at liberty to do so, taking the risk that he may pay more than the price for which he may hold the vendor at the contract date of delivery .... [The plaintiffs] could not charge the defendants with a higher price than that of the market on the contract date, but, if they had bought for less, then their loss was less, and they were bound to show how much." See also Second National Bank v. Columbia Trust Co., 288 Fed. 17 (3d Cir. 1923) ; Beale, Damages Upon Repudiation of a Contract, 17 YALE L.J. 443, $454-5$ (1908).

73. Renner Co. v. McNeff Bros., 102 F.2d 664 (6th Cir. 1939) ; Samuels v. E.F. Drew \& Co., 292 Fed. 734 (2d Cir. 1923) ; Soya Processing Co. v. Sirota, 104 F. Supp. 428 (S.D.N.Y. 1952) ; Georgia Wholesale Co. v. United States, 84 Ct. Cl. 150 (1936); Armstrong v. Walters, 223 Fed. 451 (E.D. Pa. 1915) ; Steel By-Products Co. v. McGce \& Cowart, 19 Ala. App. 29, 94 So. 268 (1922) ; Alaska Salmon Co. v. Standard Box Co., 158 Cal. 567, 112 Pac. 454 (1910) ; McNeff v. White Eagle Brewing Co., 294 Ill. App. 37, 13 N.E.2d 493 (1938) ; Kansas Flour Mills Co. v. Brandt, 98 Kan. 587, 158 Pac. 1120 (1916); Louisville Packing Co. v. Crain, 141 Ky. 379, 132 S.W. 575 (1910) ; Baessetti v. Shenango Furnace Co., 122 Minn. 335, 142 N.W. 322 (1913); New Mexico-Colorado Coal \& Mining Co. v. Baker, 21 N.M. 531, 157 Pac. 167 (1916); Benedict v. Harris, 158 Ore. 613, 77 P.2d 442 (1938) ; Aetna Explosives Co. v. Diamond Alkali Co., 277 Pa. 392, 121 Atl. 201 (1923) ; Pierce Oil Corp. v. Gilmer Oil Co., 230 S.W. 1116 (Tex. Civ. App. 1921) ; Cron \& Dehn Inc. v. Chelan Packing Co., 158 Wash. 167, 290 Pac. 999 (1930); James \& Mitchell v. Adams, 16 W. Va. 245, 267 (1880). See also Rochn v. Horst, 178 U.S. 1 (1900) (recovery of market-contract difference on repudiation acceptance date allowed even though court states performance date is time to compute damages); Con1pania Engraw Com'1 E. Ind. v. Schenley Distillers Corp., 181 F.2d 876 (9th Cir. 1950) (same).

Among these courts, there is still dispute over the correct market for measuring damages : the "spot" market, for contract for immediate delivery on the date of rcpudiation 
by covering, in many cases this is indistinguishable from the cover rule. It yields a different result when the injured party accepts the repudiation by other means. ${ }^{74}$ In such a case, even though he may subsequently cover, the measure of damages remains the difference between contract and market on the date of repudiation acceptance. This rule produces the same consequences as the cover rule: certainty to the innocent party and insecurity to the repudiator. ${ }^{75}$

\section{Uniform Sales Act ${ }^{70}$}

The Uniform Sales Act, adopted by thirty-four states, ${ }^{77}$ has not solved the damage computation problem. Section 64(3), the seller's remedy, and Section $67(3)$, the buyer's remedy, are similarly worded: "[I]n the absence of special circumstances showing proximate damages of a greater amount," the difference between the contract price and the market price at the time or times the goods ought to have been delivered shall be the measure of damages. ${ }^{78}$ But courts have interpreted the phrase "in the absence of special circumstances" in a variety of ways. Thus, they have been as free in the computation of damages as if no statute were present.

The Sales Act does not specifically include an anticipatory repudiation in the "special circumstances" category. Such an inclusion would hive eliminated anticipatory repudiations from the ordinary damage computation of market-contract difference at the performance date. Because an anticipatory repudiation is not specifically excepted from this general rule, some courts interpret the "special circumstances" clause to include only consequential damages. ${ }^{79}$ They therefore hold the Sales Act to require computation as of

acceptance, or the "futures" market, for contracts for delivery on the date of performance. While either one may generally be used, there have been decisions restricting the computation to one or the other. Compare Bisbee Linseed Corp. v. Paragon Paint \& Varnish Corp., 96 F.2d 464 (2d Cir. 1938) ("spot" contract), with Jebeles \& Colias Confectionary Co. v. Stephenson, 6 Ala. App. 103, 60 So. 437 (1912) ("future" contract). Since a recontract should be as similar to the repudiated contract as possible, the restriction to a "future" contract, where available, seems preferable.

74. A repudiation may also be accepted by bringing suit or by indicating to the repudiator that it is accepted. See cases cited note 8 supra. If an injured party accepts the repudiation by either of these two methods, a subsequent recontract will not affect the damage computation.

75. See notes 68-9 supra and accompanying text.

76. Many cases decided under the Sales Act have already been dealt with in the preceding section. Since they form an integral part of the contracts case law, eliminating them from the prior discussion would be unrealistic. The purpose of this section is not to rehash the previous discussion, but rather to analyze the rules, if any, which the Sales Act imposes.

77. 1 ULA, SALES 6 (Supp. 1953).

78. UNIFORA SALES ACT $\$ \$ 64(3), 67(3)$. It is said that these sections merely codify the common law. See Kahn v. Carl Schoen Silk Corp., 147 AId. 516, 128 Atl. 359 (1925); Banks v. Warner, 85 Conn. 613, 84 Atl. 325 (1912).

79. See Goldfarb v. Campe Corp., 99 Misc 475, 164 N.Y. Supp. 583 (City Ct. 1917).

Consequential damages are all damages reasonably foreseeable when the contract was made, other than the usual contract-market difference. See 5 WuListox, Cosimacts $\$ \$$ 
the performance date, ${ }^{80}$ unless the court holds that the duty to mitigate requires an earlier recontract. ${ }^{81}$ And a plaintiff's recontract does not then affect the computation. 82 Other courts, however, interpret the "special circumstances" clause to include a recontract. ${ }^{83}$ And a large number simply disregard the statute's apparently mandatory language. ${ }^{84}$ The latter two interpretations protect the plaintiff who covers reasonably, by measuring damages on the basis of his recontract.

Assuming that a cover contract is included in the "special circumstances" clause, a strict reading of the sections involved still prevents certainty in damage computation. The full clause reads "in the absence of special circumstances showing proximate damages of a greater amount." 85 Thus, where plaintiff recontracts after accepting a repudiation, the new contract may result in "proximate damages of a greater amount" than performance date computation. Plaintiff would then recover damages based on the difference between the old contract price and the recontract price. But if greater damages are incurred by using the performance date market price, that larger figure would be recovered. For the "special circumstances" clause only operates if "damages of a greater" amount" have been caused by the recontract. Plaintiff can thus speculate for his own benefit, but at defendant's risk. ${ }^{86}$

1344-5 (rev. ed. 1937). For cases granting consequential damages, sce, c.g., Perkins v. Minford, 235 N.Y. 301,139 N.E. 276 (1923) (performance date not used since injured buyer could not learn of breach until later); Sturgeon v. Hanson, 62 N.D. 720, 245 N.W. 481 (1932) (extra expenses incurred due to late delivery by seller); Black v. Love \& Amos Coal Co., 30 Tenn. App. 377, 206 S.W.2d 432 (1947) (buyer's lost resale profits).

80. Crane Iron Works v. Cox \& Sons, 28 F.2d 328 (3d Cir. 1928); Continental Grain Co. v. Simpson Feed Co., 102 F. Supp. 354 (E.D. Ark. 1951), modified on other grounds. 199 F.2d 284 (8th Cir. 1952) ; Joseph Denunzio Fruit Co. v. Crane, 79 F. Supp. 117 (D. Cal. 1948), rev'd on other grounds, 188 F.2d 569 (9th Cir.), cert. denicd, 342 U.S. 820 (1951) ; Segall v. Finlay, 245 N.Y. 61, 156 N.E. 97 (1927) ; Seward v. Pennsylvania Salt Manufacturing Co., $78 \mathrm{~Pa}$. Super. 319 (1922). See Churchill Grain \& Seed Co. v. Newton, 88 Conn. 130, 134, 89 Atl. 1121, 1123 (1914).

81. The Sales Act does not abrogate the common law duty to mitigate. Sec Crane Iron Works v. Cox \& Sons, 28 F.2d 328 (3d Cir. 1928). But cf. Continental Grain Co. v. Simpson Feed Co., 102 F. Supp. 354 (E.D. Ark. 1951), modified on other grounds, 199 F.2d 284 (8th Cir. 1952).

82. For a pointed illustration, see Guaranty Trust Co. v. Meer, 114 Misc. 327, 187 N.Y. Supp. 288 (Sup. Ct. 1921).

83. Renner Co. v. McNeff Bros., 102 F.2d 664 (6th Cir. 1939); Soya Processing Co. v. Sirota, 104 F.Supp. 428 (S.D.N.Y. 1952). See Goldfarb v. Campe Corp., 99 Misc. 475, 481, 164 N.Y. Supp. 583, 587 (City Ct. 1917).

84. Compania Engraw Com'l E. Ind. v. Schenley Distillers Corp., 181 F.2d 876 (9th Cir. 1950) ; Bisbee Linseed Corp. v. Paragon Paint \& Varnish Corp., 96 F.2d 464 (2d Cir. 1938); McNeff v. White Eagle Brewing Co., 294 Ill. App. 37, 13 N.E.2d 493 (1938); Goldsmith v. Stiglitz, 228 Mich. 255, 200 N.W. 252 (1924); Cron \& Dehn v. Chelan Packing Co., 158 Wash. 167, 290 Pac. 999 (1930).

85. UNiform SALES Act $\S \S 64(3), 67$ (3) (emphasis added).

86. Unless this interpretation is followed, the "special circumstances" clause is meaningless. Yet, those few courts which have discussed it, see cases cited notes 79 and 83 supra, generally disregard the "damages of a greater amount" part. Goldfarb v. Campe 


\section{Uniform Commercial Code}

Unlike the Sales Act, the Uniform Commercial Code explicitly codifies the injured party's common-law right to accept or to reject an anticipatory repudiation. ${ }^{87}$ In addition, the UCC moves toward certainty in contractual relations by the addition of a "Right to Adequate Assurance of Performance" section. ${ }^{88}$ Under this section, 2-609, one party may demand adequate assurance of performance from the other party. ${ }^{\text {s9 }}$ If this assurance is not forthcoming within a reasonable time, the requesting party may hold the contract repudiated. Hence, evidentiary problems of the presence of a repudiation are greatly diminished..$^{90}$

However, the UCC further complicates the method of damage computation for an anticipatory repudiation. It gives the injured buyer remedies different from those which it gives to the injured seller. ${ }^{91}$ And irreconcilable sections of the Code make buyer's actual remedy unclear.

\section{UCC Seller's Remedy for Anticipatory Rcpudiation}

The Code grants the injured seller the theoretical right to decide when damages shall be computed, so long as his conduct is commercially reasonable. Section 2-706 allows the seller to resell after accepting a repudiation. He may then recover the difference between the contract price and the resale price. If the seller fails to resell, or resells in a commercially unreasonable manner, his damages will be computed on the performance date contract-market difference. ${ }^{.3}$

Corp., 99 Misc. 475,164 N.Y. Supp. 583 (City Ct. 1917), is one case that explicitly holds that the "special circumstances" clause does not permit the repudiator to prove that less damages than the contract-market difference on performance date vere actually incurred.

87. Uniforas Cosmarecial Code (hereinafter cited as UCC) § 2-610.

The effect of this section on the executory limitation is far from certain. See note 36 supra.

88. UCC $\$ 2-609$.

89. Under existing case law, a party requesting adequate assurance of performance may be held to have thereby repudiated the contract. See, e.g., Hadfield v. Colter, 188 App. Div. 563, 177 N.Y. Supp. 382 (1st Dep't 1919). There, seller had notified the defendant that he would not deliver the remaining installments unless defendant agrced to pay a higher price. When defendant refused, seller delivered some. In paying for these, defendant wrote on the check that by cashing it seller agreed to complete delivcries at the specified prices. This statement was held to be a repudiation of the contract.

90. Present case law often makes it dificult for an injured party to be certain that his promisor's words or acts constitute a repudiation. See authorities cited note 7 sulfra. If he incorrectly labels them a repudiation, the "injured party" becomes the breaching party. UCC $\$ 2-609$ permits a party who is uncertain whether the contract has been repudiated to request adequate assurance of performance. Proof at trial that no assurance was forthcoming will be sufficient to prove the repudiation.

91. This inconsistency is recognized in the Report of PenN. Gen. Assersaly StrCOAras. ON THE Proposed UCC 57 (1952).

92. UCC $\$ 2-706(1)$.

93. UCC $\$ 2-708$.

However, if trial should occur prior to the performance date, damages are to be computed as of the repudiation date. UCC $\$ 2-723$. 
The Code also includes two minor limitations on the seller's freedom to choose the resale date. Only identified goods may be resold, unless there is a recognized futures' market.94 And the buyer must be given reasonable notice of the proposed resale. ${ }^{95}$ Neither requirement effectively hinders the seller's freedom of action..$^{96}$

The repudiator who wishes to limit his damages to the difference between contract and market on the date of repudiation obtains little help from the Code. The seller may resell at a time thereafter when the market is lower. If the resale is not held commercially unreasonable, the breaching buyer must bear the burden of the market's drop.

Furthermore, the Code gives little security to the many sellers who sincerely desire to minimize the repudiating buyer's liability. Most injured parties would prefer keeping losses from contract repudiations to a minimum; the prospect of prolonged litigation is a practical deterrent to increasing the loss incurred. ${ }^{07}$ Also, the good-faith injured party wants simply to be compensated for his loss. He may therefore resell immediately after repudiation, in the belief that less loss will result than if he awaits the performance date. However, a sudden turn of the market may prove him wrong. Plaintiff then risks a judicial finding that his resale conduct was not "commercially reasonable" because hindsight shows that, due to the market's actual fluctuation, greater damages were incurred by the early resale. Such a result has often occurred in those jurisdictions which presently allow recontracting if reasonable. ${ }^{98}$ Because of this hindsight danger, a plaintiff-seller can probably be certain of full compensation only if he awaits the performance date to resell. But, since the UCC does not abrogate the duty to mitigate, ${ }^{99}$ a court may find that plaintiff should have resold prior to the performance date in order to minimize damages. The new Commercial Code thus does not provide the seller with the security he deserves.

94. UCC \$ 2-706(4) (a).

A recognized futures' market is one where goods are regularly bought and sold for future delivery. See Restatement, Contracts $\$ 338$, comment b (1932).

95. UCC $\$ 2-706(4)(b)$. However, where the goods are perishable or threaten to decline in value, there is no notice requirement. Ibid.

96. If there is a recognized futures' market, no identification of the goods is required. Therefore, the injured seller is free to choose the resale date, so long as not commercially unreasonable. Furthermore, even if there is no futures' market for the goods, the seller need only identify the goods when he desires to resell. And he can probably meet the requirement of reasonable notice of resale by notifying the buyer in time for him to be present at the resale.

97. It is very doubtful that any injured party, except an extremely vindictive one, would desire to increase his loss in the hope of recovering the added loss in the form of a collectible judgment.

98. See cases cited notes 41 and 64 supra.

99. The UCC does not mention the duty to mitigate. But the Uniform Sales Act, which also disregarded this duty, was held not to have abrogated it. See Crane Iron Works v. Cox and Sons, 28 F.2d 328 (3d Cir. 1928); cf. Goldfarb v. Campe Corp., 99 Misc. 475, 164 N.Y. Supp. 583 (City Ct. 1917). There is no reason to believe that the UCC effects a change. 


\section{UCC Buyer's Remedy for Anticipatory Repudiation}

Due to irreconcilable sections, the UCC is not clear on the buyer's remedy for an anticipatory repudiation by the seller. Three different conclusions are possible: 1) computation as of repudiation, whether or not the repudiation is accepted;2) computation as of the date the repudiation is accepted except where buyer reasonably covers, in which case damages are computed as of cover; and 3) computation as of the performance date, unless the trial occurs prior thereto.

Section 2-713 requires that damages be computed as of the time the buyer "learned of the breach." It would seem that the buyer obviously learned of the breach when he learned of the seller's repudiation. Therefore, damages would be computed as of the date the buyer receives notice of the repudiation. But this interpretation would make meaningless the UCC-granted option to accept or reject a repudiation. ${ }^{100}$ For in order to be certain of full compensation, the buyer would have to accept the repudiation and repurchase. ${ }^{101}$ Undoubtedly 2-713 was not intended to apply to anticipatory repudiations. It was drafted to meet those instances where the buyer does not learn of the breach until after the date of performance. ${ }^{102}$ For example, this might occur where the contract calls for title to pass upon delivery of the goods to the carrier; the buyer could not possibly know that the goods were not delivered until a reasonable time thereafter. Yet the draftsmen's failure to consider the anticipatory repudiation problem does not affect the section's applicability to this problem.

Section 2-713 may be reconciled with the option to accept or reject a repudiation only by using the common law fiction which distinguishes a breach from a repudiation. Case law has always used the rule that a repudiation does not become a breach until accepted by the injured party. ${ }^{103}$ Assuming that the UCC accepts this fiction, ${ }^{101}$ damages would be computed as of the time when the injured party notifies himself that he has accepted the repudiation; he thereby "learn [s] of the breach!"105

100. UCC $\$ 2-610$.

This inconsistency is recognized in the Report of PENN. GeN. Assensaly Suncouss. ON THE PROPOSED UCC 52 (1952).

101. Otherwise, the injured buyer would have his damage computed on the repudiation date while his recontract, made on a different date, might cause additional loss.

102. See Texas Legislative Councin, Analysis of Article 2 of tre UCC 248-9 (1953). For an example of the problem, see Perkins v. Afinford, 235 N.Y. 301,139 N.E. 276 (1923).

103. See 5 Williston, Contracts $\$ 1322$ (rev. ed 1937).

104. This is not a difficult assumption to make since the UCC seems to distinguish between "breach" and "repudiation" by using both terms. Compare UCC $\$ 2-713$ (breach), with UCC \& 2-723 (repudiation).

105. This would then be a codification of present case law. For a repudiation may be accepted without notifying the guilty party. See, c.g., Steele By-Products Co. v. AIcGee \& Cowart, 19 Ala. App. 29, 94 So. 268 (1922).

The Texas and Pennsylvania analyses do not accept this interpretation. Rather, they conclude that damages are to be computed on the repudiation date. They then admit that this is inconsistent with $\$ \$ 2-610$ and/or 2-723. Texas Legrslative Couscil, Asalysis of 
Section 2-712 must be interpreted as an alternative remedy to computation upon acceptance of the repudiation. This section grants the injured buyer an option to cover by repurchasing. If he covers without unreasonable delay, damages will be computed on the basis of his recontract. If he fails to cover, or covers in an unreasonable manner, Section 2-713's computation as of the repudiation acceptance date will govern. ${ }^{108}$

Section 2-723(1) is impossible to reconcile with any logical interpretation of the buyer's remedy. It states that if an action for anticipatory repudiation comes to trial prior to the performance date, damages shall be based on the date the injured party learned of the repudiation. This section's obvious purpose is to avoid the difficulty of approximating a future market. ${ }^{107}$ But this difficulty would be present only if, without this section, damages were computed as of a date subsequent to the trial. This could never occur if damages were based on the repudiation acceptance or cover dates; by definition, these dates must occur prior to the trial. ${ }^{108}$ Therefore, the converse of the section must be implied: if the trial occurs after the performance date, damages shall be computed as of the performance date. But this is diametrically contrary to Sections 2-713 and 2-712, which seem to require damages based either on the date of repudiation acceptance or cover. ${ }^{100}$ Section 2-723(1) did not appear in the very early drafts of the Code. ${ }^{100}$ Apparently it was added to eliminate a problem not actually present.

Because of these conflicting sections, buyer's damage recovery under the UCC is uncertain. The most probable of the possible alternatives requires computation as of the time the repudiation is accepted, except where buyer covers reasonably, in which case damages are computed as of cover. ${ }^{111}$ This

Article 2 of the UCC 249 (1953) ; Report of Penn. Gen. Assenbly Sudconm. on tue Proposed UCC 52 (1953).

106. See UCC $\$ 2-713$, comment 5 .

107. See UCC § 2-723, comment.

108. Bringing suit for anticipatory repudiation of a contract constitutes acceptance of the repudiation. See, e.g., Barnebey v. Barron S. Collier, Inc., 65 F.2d 864 (8th Cir. 1933). Therefore, acceptance of the repudiation must occur prior to trial. And, in order to use a cover recontract for computation of damages, it must be pleaded. Therefore, cover also must occur prior to trial.

109. See text at notes 100-06 supra. Both the Texas and Pennsylvania Commissions recognize this inconsistency in their analyses. See note 105 supra. But the Pennsylvania analysis seems to have misunderstood the point completely. It claims that $\S 2-723$ is necessary because of the $\$ 2-610$ option to await the performance date. REPORT of PENN. Gen. Assembly Subcoms. on the Proposed UCC 56 (1952). But once the injured party awaits performance date, suit is no longer for anticipatory repudiation; rather, it is for present breach. Therefore, $\S 2-723$ would not be applicable in that case.

110. See Uniforar Revised Sales Act § 65 (2d Draft, 1941). That section was entitled "Determination and Proof of Market Price," but no mention of anticipatory repudiation was included. UCC § 2-723, "Proof of Market Price: Time and Place," is similar in substance except for the inclusion of proof of price in an anticipatory repudiation situation.

111. If the repudiation is not accepted, no breach occurs until the present breach on the performance date. Damages will then be computed as of that date. UCC $\$ 2-713$. 
conclusion is supported by another provision of the UCC related to the anticipatory repudiation doctrine: Section 2-609. By permitting an aggrieved party to insist upon adequate assurance of performance, this section clearly contemplates that the injured party may wish to recontract immediately upon receiving a repudiation. ${ }^{112} \mathrm{He}$ will thereby insure performance without the possibility of additional loss. But this conclusion is necessarily speculative. A new statute should not be so ambiguous. ${ }^{113}$

The UCC does make some progress, at least for the buyer-plaintiff, if this interpretation is followed. He will be fully protected if he recontracts in a reasonable manner. But he will still be in doubt if he disregards the repudiation. For a court may find that he had a duty to mitigate by repurchasing immediately at repudiation; in this situation, the common law duty to mitigate damages is not altered by the UCC. ${ }^{114}$

Furthermore, the UCC gives very little security to the repudiating seller. His repudiation does not affect damage computation until the buyer accepts it. Until then, the seller faces the danger of greater damages from a rising market. And the seller cannot feel secure even after acceptance of his repudiation unless acceptance is by cover; for cover at a later date may increase the damages.115 It was to avoid this threat of increased damages, as well as to forewarn the buyer, that seller notified buyer of his repudiation. Yet, he remains at the market's mercy. Business practices deserve more certainty than this affords.

\section{UNFINISHed Goods Contracts ${ }^{110}$}

Existing case law substantially eliminates the injured seller's ${ }^{\mathbf{1 1 7}}$ option to accept or reject a repudiation where the goods ordered are as yet unfinished. ${ }^{118}$

112. See UCC $\$ 2-609$, comment 1: "[A] buyer who believes that the seller's deliveries have become uncertain cannot safely wait for the due date of performance when he has been buying to assure himself of materials for his current manufacturing or to replenish his stock of merchandise."

113. The resultant confusion is made obvious by the difficulties of the Teras and Pennsylvania Committees which analyzed the UCC. See notes 100, 105, and 109 stipro.

114. See note 99 supra.

115. Even after accepting the repudiation, the injured buyer may cover and have his damages computed on that recontract. UCC $\$ 2-712$.

116. For want of a better label, this section is titled "Unfinished Goods Contracts." It includes any contract covering identifable goods which, at the repudiation, have not been completed. Included in this category are: 1) goods not fully manufactured; 2) goods not yet purchased by the seller for resale to the repudiator; 3 ) goods not yet delivered to the repudiator where a sizable delivery expense is involved.

117. By definition, repudiation of an unfinished goods contract requires that the seller be the injured party. If the seller repudiates, it is treated as an ordinary sales contract.

118. Henckley v. Pittsburgh Steel Co., 121 U.S. 264 (1887) ; Rockingham County v. Luten Bridge Co., 35 F.2d 301 (4th Cir. 1929); Skeele Coal v. Arnold, 200 Fed. 393 (2d Cir.), cert. denied, 226 U.S. 612 (1912) ; Kingman \& Co. v. Western Mfanufacturing Co., 92 Fed. 486 (8th Cir. 1S99), aff'd, 170 U.S. 675 (1890) ; David D. Joseph Co. v. Unitcd States, 82 F. Supp. 345 (Ct. Cl. 1949) ; Atkinson v. District Bond Co., 5 Cal. App. 2d 738, 43 P.2d 867 (1935) ; King v. Rhodes, 47 App. D.C. 316 (1918); Poinsettea Dairy Products v. Wessel Co., 123 Fla. 120, 166 So. 306 (1936) ; Holston Box \& Lumber Co. v. Vonberg \& 
For the duty to mitigate prevents an injured party from enhancing his damages. Therefore, seller cannot continue performance where a reasonable estimate would indicate that damages, measured by the difference between contract price and market price of the finished goods, would be greater than the expenses already incurred plus lost profits. ${ }^{119}$ And, if the goods are finished at the time of repudiation, seller can not ship the goods to the place of delivery when additional damages would thus result. ${ }^{120}$ Furthermore, the mitigation duty may require affirmative action by the injured party. Unless the repudiated contract represents a "lost opportunity,"121 he will be held to have obtained a new contract for his now free time. And his damages must be reduced by any profits on this new contract. ${ }^{122}$

Bates, 34 Ga. App. 298, 129 S.E. 562 (1925) ; James H. Rice Co. v. Penn Plate Glass Co., 88 Ill. App. 407 (1900) ; Hollerbach \& May Contract Co. v. Wilkins, 130 Ky. 51, 112 S.W. 1126 (1908) ; Urgent v. Mairs, 130 Mich. 609, 90 N.W. 423 (1902); Gibbons v. Bente, 51 Minn. 499, 53 N.W. 756 (1892) ; American Publishing \& Engraving Co. v. Walker, 87 Mo. App. 503 (1901) ; Baches v. Schlick, 82 Neb. 289, 117 N.W. 707 (1908); Masterson v. Mayor of Brooklyn, 7 Hill (N.Y.) 61 (1845) ; Heiser v. Mears, 120 N.C. 443, 27 S.E. 117 (1897) ; Davis v. Bronson, 2 N.D. 300, 50 N.W. 836 (1891); Advertisers Exchange, Inc. v. Bleich, 40 Ohio Abs. 212, 57 N.E.2d 91 (1943) ; A.B.C. Oil Burner v. Duncan, 28 Del. (Pa.) 528 (Com. Pl. 1939); Ault v. Dustin, 100 Tenn. 366, 45 S.W. 981 (1898); Sonka v. Chatham, 2 Tex. Civ. App. 312, 21 S.W. 948 (1893) ; Danforth \& Co. v. Walker, 40 Vt. 257 (1867); Worrell \& Williams v. Kinnear Manufacturing Co., 103 Va. 719, 49 S.E. 988 (1905) ; Nilson v. Morse, 52 Wis. 240,9 N.W. 1 (1881). See Rock v. Gaede, 111 Kan. 214, 217, 207 Pac. 323, 324 (1922). Cf. Allison Lumber Co. v. Decatur Lumber Co., 30 Ga. App. 613,118 S.E. 597 (1923). Massachusetts, although it rejects the anticipatory repudiation doctrine, see note 5 supra, also requires an injured seller to halt performance when an unfinished goods contract is repudiated. Snelling v. Dine, 270 Mass. 501, 170 N.E. 403 (1930).

119. See cases cited note 118 supra. See also Rockhill Iron \& Coal Co. v. City of Taunton, 273 Fed. 96 (1st Cir. 1921); Fail \& Miles v. McRee, 36 Ala. 61 (1860); scc Roehm v. Horst, 178 U.S. 1, 21 (1900).

120. W. H. Edgar \& Son v. Grocers' Wholesale Co., 298 Fed. 878 (8th Cir. 1924); Lagerloef Trading Co. v. American Paper Products Co., 291 Fed. 947 (7th Cir 1923), cert. denied, 263 U.S. 706 (1923) ; Rounsaville \& Bro. v. Leonard Manufacturing Co., 127 Ga. 735, 56 S.E. 1030 (1907) ; Hale v. Hess, 30 Neb. 42, 46 N.W. 261 (1890); Windmuller v. Pope, 107 N.Y. 674, 14 N.E. 436 (1887) ; Hart-Parr Co. v. Finley, 31 N.D. 130, 153 N.W. 137 (1915); Sonka v. Chatham, 2 Tex. Civ. App. 312, 21 S.W. 948 (1893); Knight \& Bostwick v. Moore, 203 Wis. 540, 234 N.W. 902 (1931). Cf. Altison Lumber Co. v. Decatur Lumber Co., 30 Ga. App. 613, 118 S.E. 597 (1923); Palestine Ice, Fuel \& Gin Co. v. Walter Connally \& Co., 148 S.W. 1109 (Tex. Civ. App. 1912).

121. A repudiated contract represents a "lost opportunity" when its performance would not have precluded the injured party from entering into similar contracts at the same time. For cases where the contract was held a "lost opportunity," see, c.g., Hollerbach \& May Contract Co. v. Wilkins, 130 Ky. 51, 112 S.W. 1126 (1908); Olds v. Mapes-Recves Construction Co., 177 Mass. 41, 58 N.E. 478 (1900) ; Canda v. Wick, 100 N.Y. 127, 2 N.E. 381 (1885).

122. See, e.g., Harrington-Ward v. Blomstrom Manufacturing Co., 166 Mich. 276, 131 N.W. 559 (1911) ; Baessetti v. Shenango Furnace Co., 122 Minn. 335, 142 N.W. 322 (1913) ; DeMoss v. Beryllium Corp., 358 Pa. 470, 58 A.2d 70 (1948). But sec Grinnell Co. v. Vorhees, 1 F.2d 693 (3d Cir.), cert. denied, 266 U.S. 629 (1924) (no duty to obtain new contract since unfair to make plaintiff use "skill, capital and time" for defend- 
The general measure of damages is, therefore, expenses incurred plus lost profits. ${ }^{123}$ Any value which the plaintiff retains in work already completed is deducted $;^{124}$ otherwise he would twice recover. ${ }^{125}$ If defendant retains some of plaintiff's work, the plaintiff may rescind ;120 he then recovers the reasonable value of the property kept by the defendant. And the fact that the plaintiff would have incurred a loss if the contract had been performed does not reduce this quantum meruit recovery. ${ }^{127}$

A small minority of decisions refuses to require cessation of performance upon repudiation. ${ }^{128}$ Their rationale is that neither party has the right unilaterally to rescind the contract; therefore, the injured party may disregard a repudiation. Upon completion of the goods, the ordinary contract-market price difference measure of damages is used. ${ }^{120}$ If there is no market for the goods, an action for the contract price is permitted. ${ }^{130}$ The number of courts which allow this rejection of repudiation is decreasing. ${ }^{131}$

\section{Uniform Sales Act}

The Uniform Sales Act has generally been interpreted to require an innocent seller to mitigate by halting performance when less damages would thereby result. ${ }^{132}$ Most courts apply Section 64(4) to unfinished goods contracts; this

ant's benefit); Allen v. Field, 130 Fed. 641 (2d Cir. 1904), cerl. denicd, 201 U.S. 649 (1906) (same).

123. See cases cited notes 118 and 119 supra.

124. See e.g., United States v. Behan, 110 U.S. 338 (18S4); General Lamps Manufacturing Corp. v. Rader, 43 Berk. (Pa.) 45 (1950); Tufts v. Laurence, 77 Tex. 526, 14 S.W. 165 (1890).

125. For he could then sell or use the work already completed.

126. See, e.g., Brady v. Oliver, 125 Tenn. 595, 147 S.W. 1135 (1911); sec United States v. Behan, 110 U.S. 338, 345 (18S4); Hosmer v. Wilson, 7 Aich. 294, 301 (1859).

127. Brady v. Oliver, supra note 126 .

128. United States v. Burton Coal Co., 273 U.S. 337 (1927) ; John A. Rocbling's Sons Co. v. Lock-Stitch Fence Co., 130 Ill. 660, 22 N.E. 518 (18S9); MicAllister v. Safeley, 65 Iowa 719, 23 N.W. 139 (1885); Mooney v. Newbern, 5 N.J. Misc. 585, 137 Atl. 567 (1927); Barber Milling Co. v. Leichthammer Baking Co., 273 Pa. 90, 116 Atl. 677 (1922).

Burton Coal, supra, illustrates the consequences of permitting completion of performance. If performance had ceased at repudiation, recovery for lost profits would have been $\$ 46,000$; on completion, damages were $\$ 450,000$. Of course, we do not lnow whether plaintiff had already incurred expenses in anticipation of fulfilling the contract. These expenses would be recovered with the lost profits. See cases cited notes 118 and 119 supro.

129. See, e.g., United States v. Burton Coal Co., sipra note 123; John A. Roebling's Sons Co. v. Lock-Stitch Fence Co., supra note 128.

130. See e.g., McAllister v. Safeley, 65 Iowa 719, 23 N.W. 139 (18S5); MLoncy v. Newbern, 5 N.J. IIisc. 585, 137 Atl. 567 (1927).

131. No holding of this type has been found in any decision after 1927.

132. Snelling v. Dine, 270 Mass. 501, 170 N.E. 403 (1930); Licberman v. Templar Motor Co., 236 N.Y. 139, 140 N.E. 222 (1923) ; Jessup \& Moore Paper Co. v. Bryant Paper Co., $297 \mathrm{~Pa}$ 483, 147 Atl. 519 (1929); Roland \& Whytock v. Rex Manufacturing Co., 49 R.I. 168, 141 Atl. 310 (1928).

Where both USA $\$ 64(3)$ and $67(4)$ are inapplicable, i.c. there is no market for the goods and there will be no substantial saving by halting performance, an action for the 
states that the buyer shall be liable for no greater damages than if the seller ceased performance immediately upon repudiation. One jurisdiction, however, limits the application of Section 64(4) to those cases where there is no available market for the goods. ${ }^{133}$ This view holds that Section $64(3)$ is mandatory whenever there is a market. That section, as previously discussed, ${ }^{134}$ computes the seller's damages, "where there is an available market for the goods," on the performance date difference between market and contract. This interpretation seems undesirable. Since Section 64(4) permits the injured seller to recover all lost profits and expenses, he gains nothing by completing performance after repudiation. Whether he goes on to incur further expenses, for which he will be reimbursed, or immediately ceases performance, his overall gain on the contract will still be only the lost profits. ${ }^{\mathbf{1 3 5}}$ Furthermore, permitting the plaintiff to complete performance creates only waste $:^{136}$ for defendant is compelled to pay greater damages than necessary in order fully to compensate the plaintiff.

\section{Uniform Commercial Code}

Although in substance the UCC also requires the cessation of performance upon repudiation, by using two ambiguous phrases and a shift of emphasis, it spreads doubt on this comparatively certain rule. Section $2-704$ gives seller the right to complete the contract "unless in reasonable commercial judgment the completion will materially increase the damages." 137 Thus, the burclen is placed upon the defendant buyer to prove the seller was commercially unreasonable in deciding to complete the contract. ${ }^{138}$ This reversil of emphasis is unwarranted. The repudiation itself should indicate that defendant desires cessation of performance, and wishes to compute his damages at that point; if he had wanted plaintiff to complete the contract, and have damages com-

contract price is permitted under $\$ 63(3)$. See, e.g., Buckman v. Millville Manufacturing Co., 17 F.2d 983 (2d Cir. 1927) ; Lannom Manufacturing Co. v. Strauss Co., 235 Iowa 97, 15 N.W.2d 899 (1944).

133. Garfield \& Proctor Coal Co. v. New York, N.H. \& H.R.R., 248 Mass. 502, 143 N.E. 312 (1924).

134. See text at notes 76-86 supra.

135. For example, assume a situation where seller's profit on a contract is $\$ 1,000$, and his cost of manufacturing is $\$ 4,000$. If a repudiation occurs prior to commencing performance, seller can sue for the $\$ 1,000$ lost profits. If he completes performance, incurs the $\$ 4,000$ expense, and recovers the $\$ 5,000$ contract price, his over-all profit is still only $\$ 1,000$.

136. See 5 Corbin, Contracts 262-3 (1951) : "[I]f repudiation occurs before full performance by the injured party, . . . his power of earning full payment by completing his own performance is gone. This is because the completion of his performance will cause economic waste."

Of course, where society needs the goods, there will be no waste to society. For if there is sufficient demand, the manufacturer will not discard the unfinished goods he retains, but will complete the performance to cover a new contract.

137. UCC \& 2-704 (emphasis added).

138. Contrary to this UCC section, all cases cited note 118 supra state that the seller of unfinished goods must halt performance upon repudiation of the contract. This is spoken 
puted as of performance date, there would have been no need to repudiate. Furthermore, the inclusion of "materially increase" adds uncertainty, particularly when combined with "reasonable commercial judgment."130 These phrases may enable a revengeful plaintiff to continue performance knowing that the damages are thus aggravated. And they provide the good faith plaintiff with no greater protection than he obtains by ceasing performance. ${ }^{140}$

\section{INSURANCE CONTRACTS}

Insurance policies are often the subject of an anticipatory repudiation action. For example, the insurance company may cancel the policy on the ground that the insured misrepresented an essential fact. ${ }^{141}$ The insurer may then tender back the premiums already paid. And it will certainly refuse to accept further premiums. ${ }^{142}$ Another common occurrence is where the insurer, claiming that the insured is no longer disabled, halts the payment of benefits under a disability insurance policy. ${ }^{143}$ It will then notify the insured that premiums must again be paid in order to continue the policy. In all such cases, the insured faces the dilemma of choosing the correct method of testing the validity of the insurer's position.

Upon an anticipatory repudiation of an insurance contract, the insured usually prefers an immediate damage action. Practical considerations make this more desirable than a suit after performance date. For in order to preserve his claim until performance date, the insured may have to make regular tender of premiums. ${ }^{144}$ More important, the security for which he contracted is then

of as an absolute requirement, subject to proof by the seller that damages were not enhanced by continuing performance. In fact, the buyer was given the burden of proving that less damages would have been incurred if the seller continued performance. Rochill Iron \& Coal Co. v. City of Taunton, 273 Fed. 96 (1st Cir. 1921).

Texas Legislative Counct,, Anatisis of ARTicle 2 of the UCC 226 (1953) recognizes that the seller's rights are broadened by this section.

139. UCC \$ 2-704 (emphasis added).

Speculation about damages based upon a future market is obviously less certain than a determination of whether "labor or expense of material amount" is still necessary to perform the contract. The latter can be made with comparative assurance; for the seller need only know whether added expenses of more than de mimimis amount are still required to complete the contract. However, under the UCC formula, the seller may complete unless, in crystal-gazing, he predicts that the market will be so poor at completion time as to cause considerable enhancement of damages.

140. See note 135 supra and accompanying text.

141. See, e.g., Cobb v. Pacific MIutual Life Ins. Co., 4 Cal. 2d 565, 51 P.2d $\$ 4$ (1935); Speer v. Phoenix 1 Iutual Life Ins. Co. 36 Hun (N.Y.) 322 (1885) ; Grand Lodge Brotherhood of R.R. Trainmen v. Martin, 218 S.W. 40 (Tex. Civ. App. 1919).

142. See, e.g., Mutual Relief Ass'n v. Ray, 173 Ark. 9, 292 S.WW. 396 (1927).

143. See, e.g., Equitable Life Assurance Society v. Pool, 189 Ark. 101, 71 S.W.2d 455 (1934) ; Donlen v. Fidelity \& Casualty Co., 117 Misc. 414, 192 N.Y. Supp. 513 (Sup. Ct. 1921); Green v. Inter-Ocean Casualty Co., 203 N.C. 767, 167 S.E. 38 (1932).

144. For decisions pointing out the insured's duty to tender premiums in order to keep the contract alive, see, e.g., MIutual Life Ins. Co. v. Hill, 193 U.S. 551 (1904); Day v. Connecticut General Life Ins. Co., 45 Conn. 480 (1878); Langan v. Supreme 
no longer present. ${ }^{145}$ For example, where a life insurance policy is involved, his beneficiary receives only a lawsuit at performance date. ${ }^{146}$ And if the courts find that the insurer correctly canceled the policy, it will be too late to remedy the error. Repudiation of a disability insurance policy presents additional problems to an insured. Repudiation there usually occurs on the insurer's notifying the insured that it will refuse to pay future disability benefits. ${ }^{147}$ Without accepting the repudiation, the insured can test the validity of the insurer's refusal to pay by suing for the next installment when due. But this action will not be res judicata as to the insurer's further duty to perform. ${ }^{148}$ Thus, the insured may be compelled to sue for each installment as it becomes due. 140 Because of these burdens and the resultant insecurity, an insured usually prefers an immediate action for all damage incurred.

Yet, a substantial number of courts do not permit an immediate damage action. ${ }^{150}$ These courts apply a strict contract rationale and therefore refuse to alter the contract, which was solely a promise to pay money at a specified

Council American Legion of Honor, 174 N.Y. 266, 66 N.E. 932 (1903). But cf. Waylaud v. Western Life Indemnity Co. 166 Mo. App. 221, 148 S.W. 626 (1912).

145. See, e.g., Washington Life Ins. Co. v. Lovejoy, 149 S.W. 398, 405 (Tex. Civ. App. 1912); "By the breach ... the insured . . . not only loses the assurance which he thought he had ...., but he has been lulled into a sense of security, his activity in procuring other insurance at a time when he was an insurable risk has been stifled, and he awalies when too late to avoid it to find that he has no insurance ...."

146. It is doubtful that any insured or beneficiary would feel secure with this knowledge. Without discussing this factor, the New York Court of Appeals, however, in Langan v. Supreme Council of American Legion of Honor, 174 N.Y. 266, 66 N.E. 932 (1903), thought this expectation was sufficient security.

147. See cases cited note 143 supra.

148. See, e.g., United Fidelity Life Ins. Co. v. Dempsey, 193 Ark. 204, 98 S.W.2d 943 (1936) (first trial) ; 197 Ark. 221, 122 S.W.2d 170 (1938) (second trial after insurer again refused payments of benefits). See also Green v. Inter-Ocean Casualty Co., 203 N.C. 767,167 S.E. 38 (1932). However, the disability finding may be res judicata if the total disability is, in view of modern scientific knowledge, permanent, Pacific Mutual Life Ins. Co. v. Berryhill, 69 S.W.2d 784 (Tex. Civ. App. 1934) (loss of use of hand and foot), or if the insurance policy requires continued benefits after the instured is once totally disabled, John Hancock Mutual Life Ins. Co. v. Large, 230 Ala. 621, 162 So. 277 (1935).

149. For a striking illustration of the harassment and trouble this may cause the insured, see the two decisions in United Fidelity Life Ins. Co. v. Dempscy, supra note 148. The court in the first trial held that the insured was totally disabled, but refuscd to permit recovery of all future benefits. It granted judgment for the benefits due on December 1, 1936. Subsequently, in the early part of 1937, the insurer again ceased paying benefits, alleging no disability. Presumably in need of funds, the insured settled out of court for a smaller sum than actually due him. When the insurer remained obstinate, the insured was required to sue again; but he recovered only the installments then duc.

If the insurer is even more obstinate than the defendant in Dempscy, one court statcd that it would find some remedy. See Cobb v. Pacific Mutual Life Ins. Co., 4 Cal. 2d 565, 51 P.2d 84 (1935). Furthermore, the requirement of more than one suit to determine disability may add to already clogged dockets. John Hancock Mutual Life Ins. Co. v. Large, 230 Ala. 621, 162 So. 277 (1935).

150. Life insurance policies: New York Life Ins. Co. v. Viglas, 297 U.S. 672 (1936) (alternate holding); Kelly v. Security Mutual Life Ins. Co., 186 N.Y. 16, 78 N.E. 584 
future time. ${ }^{151}$ As a consequence of this view, the life insurance beneficiary retains only a law suit; and the disability-insured may have to sue for each installment when due.

To remedy the inequity of prohibiting an immediate damage action, some of these courts grant specific performance. ${ }^{152}$ In what is, in effect, a declaratory judgment action, the insurer is ordered to pay the insurance benefits when due. Thus, specific performance is more satisfactory than a performance date suit, for it grants the insured the security for which he bargained. But it still deprives him of the more adequate relief afforded by an immediate damage suit. Not only does he receive no money in hand, but he is also compelled to maintain a contractual relationship that is strained due to litigation caused by the insurer. ${ }^{153}$

(1906) ; Grand Lodge Brotherhood of R.R. Trainmen v. Martin, 218 S.IV. 40 (Tex. Civ. App. 1919).

Disability insurance policies: United States v. Worley, 281 U.S. 339 (1930); Hines v. Fidelity Mfutual Life Ins. Co., 6 F. Supp. 692 (E.D. N.Y. 1934) ; Parks v. Mfaryland Casualty Co., 59 F.2d 736 (W.D. Mo. 1932) ; Erreca v. Western States Life Ins. Co., 19 Cal. 2d 383, 121 P.2d 689 (1942); Aetna Life Ins. Co. v. Dorman, 51 Ga. App. 393, 180 S.E. 640 (1935); Equitable Life Assurance Society v. Goble, $254 \mathrm{Ky} .614$, 72 S.W.2d 35 (1934); Mfelancon v. Provident Life \& Accident Ins. Co., 176 La. 1055, 147 So. 346 (1932); Rishmiller v. Prudential Ins. Co., 192 Minn. 348, 256 N.W. 187 (1934) ; Allen v. National Life \& Accident Ins. Co., 228 Mo. App. 450, 67 S.W.2d 534 (1934) ; Robbins v. Travelers' Ins. Co., 155 Mlise. 384, 278 N.Y. Supp. 144, aff'd, 242 App. Div. 816, 275 N.Y. Supp. 645 (1st Dep't 1934) ; Green v. Inter-Ocean Casualty Co., 203 N.C. 767, 167 S.E. 38 (1932); Mfid-Continent Life Ins. Co. v. Christian, 164 Okla. 161, 23 P.2d 672 (1932).

Massachusetts, which rejects the anticipatory repudiation doctrine, of course refuses an immediate action upon repudiation of an insurance policy. Porter v. Supreme Council American Legion of Honor. 183 Mass. 326, 67 N.E. 238 (1903).

151. See, e.g., Aetna Life Ins. Co. v. Dorman, 51 Ga. App., 393, 395, 180 S.E. 640, 641 (1935) ;Langan v. Supreme Council American Legion of Honor, 174 N.Y. 266, 269, 66 N.E. 932, 933 (1903); Mid-Continent Life Ins. Co. v. Christian, 167 Okla. 161, 163-4, 23 P.2d 672, 675 (1932).

152. John Hancock Mutual Life Ins. Co. v. Large, 230 Ala. 621 , 162 So. 277 (1935); Brix v. People's Mutual Life Ins. Co., 18 P.2d 103 (Cal. Ct. App. 1933); Equitable Life Assurance Society v. Goble, 254 Ky. 614, 72 S.W.2d 35 (1934); Melancon v. Provident Life \& Accident Ins. Co., 176 La. 1055, 147 So. 346 (1932); Kelley v. Security Mfutual Life Ins. Co., 186 N.Y. 16, 78 N.E. 584 (1906) ; Cf. Bass v. Life \& Annuity Ass'n, 96 Kan. 205, 150 Pac. 588 (1915) ; See Supreme Council American Legion of Honor v. Jordan, 117 Ga. 808, 810, 45 S.E. 33, 34 (1903). Mierrick v. Northwestern National Life Ins. Co., 124 Wis. 221, 226, 102 N.W. 593, 594 (1905).

153. See Kelly v. Security Mutual Life Ins. Co., 186 N.Y. 16, 27, 78 N.E. 584, 588 (1906) (dissenting opinion).

In contrast with this insurance rule, upon breach of a sales contract the injured party is usually not required to accept another offer from the repudiator; he is held to have the right to say that he has no faith that defendant will fulfill his obligations. See Canadian Industrial Alcohol Co. v. Dunbar Mlolasses Co., 258 N.Y. 194, 179 N.E. 3\$3 (1932).

Furthermore, a specific performance action requires the insured to engage in litigation merely to reinstate his policy. Wayland v. Western Life Indemnity Co., 166 Ifo. App. 221, 148 S.W. 626 (1912). 
Other courts disallow even this specific performance action. ${ }^{154}$ Insurance benefits, they argue, are always contingent upon a future occurrence. Therefore, any decree ordering future performance would be uncertain in time and amount. And as all judgments must be definite, ${ }^{165}$ these courts permit the insured to recover only already due installments.

While prohibiting specific performance is certainly unreasonable, limiting the insured to this remedy is counter to equity-law distinctions. ${ }^{150} \mathrm{~A}$ legal remedy is not usually denied because there is an adequate remedy in equity; rather, it is the equitable remedy that is denied when there is an adecluate remedy at law. ${ }^{157}$ Yet here, some courts grant specific performance instead of an available and adequate legal remedy-damages. They reason that this enforces the contract as written. But, absent special circumstances requiring equity jurisdiction, no courts apply this rationale in other contract cases. For example, if a seller refuses to deliver a ton of coal to his buyer, no court would order the delivery even though that would give the buyer the coal for which he contracted. ${ }^{158}$ Instead, he would be left to his damage remedy. No special reasons appear to require a different rule here.

Even where an anticipatory repudiation action is permitted, ${ }^{160}$ courts are reluctant to find a repudiation; instead, a repudiation is sometimes labeled only

154. Brotherhood of Locomotive Firemen v. Simmons, 190 Ark. 480, 79 S.W.21 419 (1935); Green v. Inter-Ocean Casualty Co., 203 N.C. 767, 167 S.E. 38 (1932).

155. Brotherhood of Locomotive Firemen v. Simmons, supra note 154; see, gencrally, 30 AM. Jur, Judgments \& 20 (1940).

156. O'Neill v. Supreme Council American Legion of Honor, 70 N.J.L. 410, 57 Atl. 463 (1904). See also Sovereign Camp, W.O.W. v. Penn., 173 Miss. 93, 161 So. 6\&1 (1935); Merrick v. Northwestern National Life Ins. Co., 124 Wis. 221, 102 N.W. 593 (1905).

157. O'Neill v. Supreme Council American Legion of Honor, supra note 156; see McClintock, EQuity 47 (2d ed. 1948).

158. See, generally, id. at 149.

159. Life insurance policies: Mutual Relief Ass'n v. Ray, 173 Ark. 9, 292 S.W. 396 (1927) ; Bass v. Life Annuity Ass'n, 96 Kan. 205, 150 Pac. 588 (1915); Wollman v. Brotherhood of American Yeomen, 231 Mo. App. 36, 95 S.W.2d 645 (1936); O'Neill v. Supreme Council American Legion of Honor, 70 N.J.L. 410, 57 Atl. 463 (1904); Speer v. Phoenix Mutual Life Ins. Co., 36 Hun (N.Y.) 322 (1885); American Ins. Union v. Woodward, 118 Okla. 248, 247 Pac. 398 (1926) ; Pack v. Metropolitan Life Ins. Co., 178 S.C. 272, 182 S.E. 747 (1935) ; Protective Mutual Life Ins. Ass'n v. Duke, 91 S.W.2d 753 (Tex. Civ. App. 1936) ; Clemmitt \& Wife v. New York Life Ins. Co., 76 Va. 355 (1882) ; Franklin v. Northern Life Ins. Co., 4 Wash. 2d 541, 104 P.2d 310 (1940) ; Merrick v. Northwestern National Life Ins. Co., 124 Wis. 221, 102 N.W. 593 (1905) ; Cf. Watson v. Massachusetts Mutual Life Ins. Co., 140 F.2d 673 (D.C. Cir. 1943) (repudiation held present material breach of promise to give continuous insurance protection); sec Indianta Life Endowment Co. v. Carnithan, 62 Ind. App. 567, 579, 109 N.E. 851, 854-5 (1915).

Disability insurance policies: Williams v. Mutual Benefit Health \& Accident Ass'n, 100 F.2d 264 (5th Cir. 1938); Equitable Life Assurance Society v. Pool, 189 Ark: 101, 71 S.W.2d 455 (1934); Metropolitan Life Ins. Co. v. Schneider, 99 Ind. App. 590, 193 N.E. 690 (1935) ; Levy v. Massachusetts Accident Co., 124 N.J. Eq. 420, 2 A.2đl 341 (1938); McLaughlin v. Brotherhood of R.R. Trainmen, 216 S.C. 233, 57 S.E.2d 411 (1950) ; Universal Life \& Accident Ins. Co. v. Sanders, 129 Tex. 344, 102 S.W.2d 405 (1937). Cf. Pierce v. Tennessee Coal, I. \& R.R., 173 U.S. 1 (1899); Caminetti v. 
an erroneous use of defenses under the contract.160 Thus, courts have denied an action for anticipatory repudiation when an insurer canceled on the ground of a claimed misrepresentation ${ }^{101}$ or an alleged failure to pay" premiums, ${ }^{162}$ or where the insurer refused to pay disability benefits. ${ }^{103}$ This would never occur in an action on any other contract. To illustrate: $S$ contracts to sell gouds to $B$ on sixty days credit, and ships them to $B$. After inspecting the goods, $B$ refuses to accept them, alleging that they are non-conforming. This is certainly a good defense under the contract. Yet, if $B$ erroneously uses this deiense-if the goods are actually conforming $-S$ can sue immediately for damages for breach of contract. That $B$ is willing to be bound by the contract if the goods are actually conforming is of no avail. For the court would decide that $B$ 's mistake was a breach of contract. ${ }^{101}$ Similarly, an inmediate damage action should be permitted for erroneous use of defenses under an insurance contract. ${ }^{165}$

The measure of damages for anticipatory repudiation of an insurance policy is uncertain only because courts fail to distinguish between damages and the recovery in a rescission action. ${ }^{166}$ An injured party always has the option to rescind a repudiated contract. ${ }^{167}$ He then recovers all premiums paid for which he has received no consideration. ${ }^{168}$ In a damage suit, the recovery is quite

Manierre, 23 Cal. 2d 94, 142 P.2d 741 (1943); Travelers Ins. Co. v. Laneaster, 51 Ga. App. 390, 180 S.E. 641 (1935). See also Federal Life Ins. Co. v. Raseug, 12 I:.2d 693 (6th Cir. 1926), disapproved, New York Life Ins. Co. v. Viglas 297 U.S. 672 (1936).

However, this right to an action for anticipatory repudiation of a disability insurance policy is rapidly becoming more and more theoretical. See cases cited note $160 \mathrm{infra}$, and accompanying text.

160. United Fidelity Life Ins. Co. v. Dempsey, 197 Ark. 221, 122 S.152d 170 (1933); Englehart v. Volunteer State Life Ins. Co., 195 S.W.2d 798 (Tex. Civ. App. 1946). See also Mobley v. New York Life Ins. Co., 295 U.S. 632 (1935); Kimel v. Jlissuuri State Life Ins. Co., 71 F.2d 921 (10th Cir. 1934) ; Box v. Metropolitan Life Ins. Co., 232 Ala. 447, 168 So. 220 (1935); Cobb v. Pacific Mfutual Life Ins. Co., 4 Cal.2d \$65, 51 P.24 84 (1935) ; Indiana Life Endowment Co. v. Reed, 54 Ind. App. 450, 103 N.E. 77 (1913); Rishmiller v. Prudential Ins. Co., 192 Mfinn. 348, 256 N.W. 187 (1934).

These decisions have been cited by one commentator as authurity that "[i]t is clear that the insurer which claims, although erroneously, that the insurance is not . . . disabled . . . does not . . . incur liability" for an anticipatory repudiation. VA:ace, IssterANCE 357 (3d ed. 1951). While the trend away from allowing an anticipstory rejudiation action on a disability insurance policy does seem to be gaining mumentum, the cases cited note 159 supra are still good law, i.e., when a repudiation is found, an immediate action for all damages is permitted.

161. See Cobb v. Pacific Miutual Life Ins. Co., supra note 160.

162. See New York Life Ins. Co. v. Viglas, 297 U.S. 672 (1936).

163. See Rishmiller v. Prudential Ins. Co., 192 Minn. 348, 256 N.IV. 187 (1934).

164. See, e.g., Baesseti v. Shenango Furnace Co., 122 Minn. 335, 142 N.W. 322 (1913).

165. See, e.g., Aetna Life Ins. Co. v. Davis, 187 Ark 398, 60 S.W. $2 \mathrm{~d} 912$ (1933);

Protective Mlutual Life Ins. Ass'n v. Duke, 91 S.W.2d 753 (Tex. Civ. App. 1936).

166. See Rogers v. Jefferson Standard Life Ins., 182 S.C. 51, 189 S.E. 432 (1936);

Illinois Bankers' Life Assurance Co. v. Garrison, 48 S.W.2d 742 (Tex Civ. Aij. 1932).

167. See, e.g., Life \& Casualty Ins. Co. v. Baber, 168 Tenn. 347, 79 S.W.2d 30 (1935); Mutual Relief Ass'n v. Ray, 173 Ark. 9, 292 S.W. 396 (1927); Levy v. Massacluusetts Accident Co., 124 N.J. Eq. 420,2 A.2d 341 (1938).

168. Capital City Benevolent Society v. Travers, 4 F.2d 290 (D.C. Cir. 1925); Lnity 
different. On a disability insurance policy, the insured should recover the present value of all future benefits based on his life expectancy. ${ }^{100}$ If the sub. ject of a life insurance policy is still insurable, the additional amount necessary to maintain a similar insurance policy should be recovered. ${ }^{170}$ If no longer insurable, the amount recoverable should be the face value of the policy, less premiums that would have been paid through the insured's life expectancy, both separately discounted to the date of recovery. ${ }^{171}$ These methods fully compensate the insured for his loss. ${ }^{172}$

\section{Employment Contracts}

Considerable difference of opinion exists over the extent to which the anticipatory repudiation doctrine is applicable to employment contracts. ${ }^{173}$ The in-

Life Ins. Co. v. Beasley, 64 Ga. App. 277, 13 S.E.2d 32 (1941); Sovereign Camp, W.O.W. v. Penn, 173 Miss. 93, 161 So. 681 (1935); McLaughlin v. Brotherhood of R.R. Trainmen, 216 S.C. 233, 57 S.E.2d 411 (1950); Grand United Order of Odd Fellows v. Massey, 87 S.W.2d 310 (Tex. Civ. App. 1935).

There is disagreement, however, over whether the time that the insurance policy was in effect constitutes consideration for the premiums paid. Comparc Lovell v. St. Louis Mutual Life Ins. Co., 111 U.S. 264 (1884) (consideration), with Life \& Casualty Co. v. Baber, 168 Tenn. 347, 79 S.W.2d 36 (1935) (no consideration). Since the insured was protected during that period, the better view is that this was consideration.

169. Pierce v. Tennessee Coal, I. \& R.R., 173 U.S. 1 (1898); Federal Life Ins. Co. v. Rascoe, 12 F. 2d 693 (6th Cir. 1926), disapproved on other grounds, New York Life Ins. Co. v. Viglas, 297 U.S. 672 (1936); Williams v. Mutual Benefit Health \& Accident Ass'n, 100 F.2d 264 (5th Cir. 1938) ; National Life \& Accident Ins. Co. v. Whitficld, 186 Ark. 198, 53 S.W.2d 10 (1932); Caminetti v. Manierre, 23 Cal. 2d 94, 142 P.2d 741 (1943) ; Metropolitan Life Ins. Co. v. Day, 145 Ga. 425, 89 S.E. 576 (1916) ; Metropolitan Life Ins. Co. v. Schneider, 99 Ind. App. 570, 193 N.E. 690 (1935); Universal Life \& Accident Ins. Co. v. Sanders, 129 Tex. 344, 102 S.W.2d 405 (1937).

If the insured is not permanently disabled, the period of the disability will have to be approximated. This should present no undue difficulty; for precisely the same thing is done in computing tort damages.

170. Speer v. Phoenix Mutual Life Ins. Co., 36 Hun (N.Y.) 322 (1885); Pack v. Metropolitan Life Ins. Co., 178 S.C. 272, 182 S.E. 747 (1935); Universal Life Ins. Co. v. Binford, 76 Va. 103 (1882); Merrick v. Northwestern National Life Ins. Co., 124 Wis. 221, 102 N.W. 593 (1905) ; Cf. Bass v. Life \& Annuity Ass'n, 96 Kan. 205, 150 Pac. 588 (1915) ; see Watson v. Massachusetts Mutual Life Ins. Co., 140 F.2d 673, 677 (D.C. Cir.), cert. denied, 322 U.S. 746 (1943).

171. Speer v. Phoenix Mutual Life Ins. Co., 36 Hun (N.Y.) 322 (1885); American Ins. Union v. Woodward, 118 Okla. 248, 247 Pac. 398 (1926); Protective Mutual Life Ins. Ass'n v. Duke, 91 S.W.2d 753 (Tex. Civ. App. 1936); Franklin v. Northern Life Ins. Co., 4 Wash. 2d 541, 104 P.2d 310 (1940); Merrick v. Northwestern National Life Ins. Co., 124 Wis. 221, 102 N.W. 593 (1905); Clemmett \& Wye v. New York Life Ins. Co., 76 Va. 355 (1882) ; cf. Wayland v. Western Life Indemnity Co., 166 Mo. App. 221, 148 S.W. 626 (1912).

172. And the insurer cannot complain. See O'Neill v. Supreme Council American Legion of Honor, 70 N.J.L. 410, 413, 57 Atl. 463, 465 (1904): "'The man who wrongfully renounces a contract into which he has deliberately entered cannot justiy complain if he is immediately sued for a compensation in damages by the man whom he has injured ...?" (quoting from Hochster v. De La Tour, 2 E. \& B. 678 (1853)).

173. See American Trading Co. v. Steele, 274 Fed. 774 (9th Cir. 1921). 
jured party is usually granted the option to accept or disregard the repudiation up to the date performance is supposed to commence. ${ }^{174}$ MIost courts refuse to apply the doctrine beyond that date. ${ }^{170}$ Instead, they label the repudiation a present breach on the ground that the repudiation joined with a present refusal to perform is a material breach of contract. ${ }^{170}$ But the difference between a repudiation joined with a present refusal to perform and a repudiation prior to the date on which performance is to commence is not sufficient to warrant this distinction. A simple example illustrates this lack of substantial difference: $M$ contracts to employ $S$ from July 1,1954 to June 30, 1956. If $M$ repudiates on June 30,1954 , this is labeled an anticipatory repudiation. But if the repudiation occurs only 24 hours later, these courts call it a present breach. Yet, any recovery by $S$ will still be almost entirely for M's repudiation of his promise to pay salary for the one year and 364 days in the future. In fact, if $S$ were interested only in the present breach, i.e., the refusal to allow him to work on July 1,1954 , it is doubtful that he would ever bother to bring suit. ${ }^{177}$ Logically, therefore, if the injured party is allowed the option to accept or disregard the repudiation in one of these fact situations, he should be permitted this option in the other. ${ }^{178}$

174. See, e.g., Sarle v. School District No. 27, 32 Ariz. 96, 255 Pac. 994 (1927); Old Ladies Home Ass'n v. Hall, 212 MFiss. 67, 52 So. $2 d 650$ (1951); Tate v. School District No. 11, 324 M1o. 477, 23 S.W.2d 1013 (1929).

175. Taylor v. Tulsa Tribune Co., 136 F.2d 981 (10th Cir. 1943); Granuw v. Adler, 24 Ariz. 53, 206 Pac. 590 (1922); Wood v. Girot, 102 Cal. App. 160, 282 Puc. 981 (1929); Ogden-Howard Co. v. Brand, 7 Boyce (Del.) 482, 108 Atl. 277 (1919) ; Dohtrty v. Schipper \& Block, 260 IIl. 128, 95 N.E. 74 (1911); Richardson v. The Eagle Machine Works, 78 Ind. 422 (1881) ; Harrington v. Empire Cream Separator Co., 120 Me. 383, 115 Atl. 89 (1921) ; Hippodrome Co. v. Lewis, 130 Mfd. 154, 100 Atl. 78 (1917); MfeCullen v. Dickinson Co., 60 MIinn. 156, 62 N.W. 120 (1895); Tate v. School District No. 11, 324 Mo. 477, 23 S.W.2d 1013 (1929); Brown v. Cowles, 72 Neb. 890,101 N.W. 1020 (1904) ; Meyers v. Potoker, 3 N.J. Misc 450, 128 Atl. 601 (1925) ; James v. Ecard of Commissioners of Allen Co., 44 Ohio St. 226, 6 N.E. 246 (1886) ; Ditzler Dry Goods Co. v. Sanders, 44 Okla. 678, $146 \mathrm{Pac} 17$ (1915); Smith v. Pallay, 130 Ore. 282, 279 Pac. 279 (1929) ; Jienihan Co. v. Hopkins, 129 Tenn. 24, 164 S.IV. 775 (1914); Niles v. Parsons, 239 S.W.2d 740 (Tex. Civ. App. 1951); Virginia Talc \& Soupstone Co. v. Hurkamp, 124 Va. 721, 98 S.E. 681 (1919); Jameson v. Board of Edueation, 78 W. Va. 612, 89 S.E. 255 (1916); see Bufkin v. Baird \& Roper, 73 N.C. 283, 292 (1875).

Contra (injured party allowed option to sue immediately or to await completion of performance; the latter is sometimes labeled the Constructive Service Doetrine): American Trading Co. v. Steele, 274 Fed. 774 (9th Cir. 1921); Russell v. Barnes Foundation, 52 F. Supp. 827 (E.D. Pa. 1943), aff'd, 143 F.2d 871 (3d Cir.), cert. denicd, 323 U.S. 771 (1944); S. Blumenthal \& Co. v. Bridges, 91 Ark. 212, 120 S.W. 974 (1909); PallardyWatrous Ins. Agency v. M. Tucker Inc, 120 Fla. 895, 163 So. 234 (1935); Moore v. Kelley \& Jones Co., 111 Ga. 371, 36 S.E. 802 (1900); Goodrich v. Hubbard, 51 Mich. 62 (1883) ; Hollwedel v. Duffy-Mott Co., 263 N.Y. 95, 188 N.E. 266 (1933) (cites anticipatory repudiation cases as authority); Allen v. Colliery Engineers' Co., $196 \mathrm{~Pa}$. 512, 46 Atl. 899 (1900) ; Sistare v. People's Supply Co., 87 S.C. 171, 69 S.E. 152 (1910). Sec Marx v. Miller, 134 Ala. 347, 351, 32 So. 765, 766 (1902).

176. See cases cited note 175 supra.

177. The expense of litigation would make such a suit prohibitive.

178. For a critical discussion of this alleged distinction, see e.g., Koehm v. Horst, 178 U.S. 1, 19 (1900) ; O'Neill v. Supreme Council American Legion of Hunor, 70 N.J.L. 
Disagreement over when an injured party may sue is a necessary corollary of this supposed distinction between an anticipatory repucliation and a present breach. If defendant's conduct is labeled an anticipatory repudiation, the injured party may accept the repudiation and sue immediately for all damages. ${ }^{170}$ Or he may choose to await each performance date, treating each clue installment as a separate cause of action. ${ }^{180}$ On the other hand, those courts which characterize the repudiation as a present breach at the time performance was to begin hold that the sole cause of action then accrues. ${ }^{181}$ And a majority permits an immediate suit by the injured party for all damages incurred. ${ }^{182}$ However, a substantial minority allows recovery of only those damages in-

410, 57 Atl. 463 (1904). Professor Williston, however, defends the distinction. 5 WilLISTON, CONTRACTS $\S 1317$ (rev. ed. 1936).

Some courts have used the label anticipatory repudiation for an action by an employce discharged during performance. See, e.g., Russell v. Barnes Foundation, 52 F. Supp. 827 (E.D. Pa. 1943), aff'd, 143 F.2d 871 (3d Cir. 1944); In re Paramount Publix Corp., 85 F.2d 42 (2d Cir. 1936) ; Pallardy-Watrous Ins. Agency v. M. Tucker, Inc., 120 Fla. 805, 163 So. 284 (1935).

179. American Trading Co. v. Steele, 274 Fed. 774 (9th Cir. 1921) ; Russel v. Barnes Foundation, 52 F. Supp. 827 (E.D. Pa. 1943), aff'd, 143 F.2d 871 (3d Cir.), ccrt. denirl, 323 U.S. 771 (1944); Sarle v. School District No. 27, 32 Ariz. 96, 255 Pac. 994 (1927); S. Blumenthal \& Co. v. Bridges, 91 Ark. 212, 120 S.W. 974 (1909); Morrison v. Sycamore Canyon Gravel Co., 102 Cal. App. 536, 283 Pac. 34 (1929); PallardyWatrous Ins. Agency v. M. Tucker Inc., 120 Fla. 895, 163 So. 284 (1935); Moure v. Kelley \& Jones Co., 111 Ga. 371, 36 S.E. 802 (1900) ; Rayburn v. Comstock, 80 Mich. 448, 45 N.W. 378 (1890); Hollwedel v. Duffy-Mott Co., 263 N.Y. 95, 188 N.E. 206 (1933); Allen v. Colliery Engineers' Co., 196 Pa. 512, 46 Atl. 899 (1900); Sistare v. People's Supply Co., 87 S.C. 171, 69 S.E. 152 (1910).

180. S. Blumenthal \& Co. v. Bridges, supra note 179; Moore v. Kelley \& Jontes Co., supra note 179; Ga Nun v. Palmer, 202 N.Y. 483, 96 N.E. 99 (1911); Worner v. Werner, 169 App. Div. 9, 154 N.Y. Supp. 570 (1st Dep't 1915); Allen v. Colliery Engineers' Co., supra note 179; Sistare v. People's Supply Co., supre note 179; cf. Russel v. Carver, 208 Ala. 219, 94 So. 128 (1922).

181. See cases cited note 175 supra.

182. Taylor v. Tulsa Tribune Co., 136 F.2d 981 (10th Cir. 1943) ; Ransome Concrete Machinery Co. v. Moody, 282 Fed. 29 (2d Cir. 1922); Granow v. Adler, 24 Ariz. 53, 206 Pac. 590 (1922) ; Wood v. Girot, 102 Cal. App. 160, 282 Pac. 981 (1929) ; Viall v. Lionel Manufacturing Co., 90 Conn. 694, 98 Atl. 329 (1916) ; Ogden-Howard Co. v. Brand, 30 Del. (7 Boyce) 482, 108 Atl. 277 (1919); Hazen v. Cobb, 96 Fla. 151, 117 So. 853 (1928); Hamilton v. Love, 152 Ind. 641, 53 N.E. 181 (1899); Bridgeford \& Co. v. Meagher, 144 Ky. 479, 139 S.W. 750 (1911); Sutherland v. Wyer, 67 Me. 64 (1877); Hippodrome Co. v. Lewis, 130 Md. 154, 100 Atl. 78 (1917) ; Edwards v. Slate, 184 Mass. 317,68 N.E. 342 (1903) ; Webb v. Depew, 152 Mich. 698, 116 N.W. 560 (1908) ; Prichard v. Martin, 27 Miss. 305 (1854); Tate v. School District, 324 Mo. 477, 23 S.W.2d 1013 (1930); School District of Omaha v. McDonald, 68 Neb. 610, 94 N.W. 829 (1903) ; Davis v. Dodge, 126 App. Div. 469, 110 N.Y. Supp. 787 (2d Dep't 1908); James v. Board of Commissioners of Allen County, 44 Ohio St. 226, 6 N.E. 246 (1886); Ditzler Dry Goods Co. v. Sanders, 44 Okla. 678, 146 Pac. 17 (1915); Quick v. Swing, 53 Ore. 149, 99 Pac. 418 (1909); Allen v. Colliery Engineers' Co., 196 Pa. 512, 46 Atl. 899 (1900); Sistare v. Pcople's Supply Co., 87 S.C. 171, 69 S.E. 152 (1910) ; Helfferich v. Sherman, 28 S.D. 627, 134 N.W. 815 (1912); Menihan Co. v. Hopkins, 129 Tenn. 24, 164 S.W. 775 (1913); G. A. Kelly Plow Co. v. London, 59 Tex. Civ. App. 208, 125 S.W. 974 (1910); Virginia Talc \& Soapstone Co. v. Hurkamp, 124 Va. 721 (1919); Jameson v. Board of Education, 78 
curred prior to the date of trial. ${ }^{183}$ This view seems to rest on the theory that plaintiff's damages cannot be estimated in advance. ${ }^{185}$ It is surprising that this should trouble a court, for in all anticipatory repudiation actions courts may grant recovery prior to the date of performance. ${ }^{185}$

Where a court labels the repudiation a present breach, the doctrine of res judicata often deprives plaintiff of full compensation. ${ }^{180}$. For example, a wrongfully discharged employee may sue for one already due installment, in the belief that the anticipatory repudiation doctrine allows him to sue at each installment date. ${ }^{187}$ If, after recovering the accrued installment, he later sues for a second installment or for damages on the entire contract, a court may hold that the repudiation plus the initial refusal to permit the employee to perform constituted a material breach. Therefore, only one cause of action arose. And the employee's prior suit for just one salary installment is then res judicata to any further recovery on the same cause of action. ${ }^{188}$ The same difficulty also exists where the court permits immediate suit only for damages accrued up to the trial date; even though the recovery was limited by the court, the plaintiff, having once litigated, cannot again bring suit. ${ }^{180}$

In those jurisdictions where the cause of action immediately accrues but recovery is limited to damages suffered up to the trial date, the statute of limitations may combine with the res judicata doctrine to make full recovery impossible. If the jurisdiction's statute of limitations is shorter than the duration of the contract, plaintiff must bring an action prior to the contract's termi-

W. Va 612, 89 S.E. 255 (1916). Cf. S. Blumenthal \& Co. v. Bridges, 91 Arl: 212, 120 S.W. 974 (1909).

183. Schroeder v. California Yukon Trading Co., 95 Fed. 296 (N.D. Calii. 1899); Darst v. Mathieson Alkali Works, S1 Fed. 284 (C.C.W.D. Va. 1896); Mars v. Miller, 134 Ala. 347, 32 So. 765 (1902); Van Winkle v. Satterfield, 3S Ark. 617, 25 S.W. 1113 (1894); Dumas v. Dumas, 84 Ga. App. 265, 66 S.E.2d 129 (1951) ; Mt. Hope Cemetery v. Weidenman, 139 Ill. 67,28 N.E. 834 (1891); Mfclfullen v. Dickinson Co., 60 Minn. 156, 62 N.W. 120 (1895); Robinson v. McAlhaney, 216 N.C. 674, 6 S.E.2d 517 (1940); Niles v. Parsons, 239 S.W.2d 740 (Tex. Civ. App. 1951); Gordon v. Brewster, 7 Wis. 355 (1859) ; cf. Brown v. Cowles, 72 Neb. 396, 101 N.W. 1020 (1904).

184. See, e.g., Van Winkle v. Satterfield, supra note 183.

185. See, e.g., L. Hand, J. in Equitable Trust Co. v. Western Pacific Ry., 244 Fed. 485, 504 (S.D.N.Y. 1917), aff'd, 250 Fed. 327 (2d Cir.), cert. deuicd, 246 U.S. 672 (1918); "It is true that the [repudiator's] obligation is changed from a series in the future to a gross sum down, but that is a consequence ... from his breach, which is a wrong and within his own choice."

186. See, e.g., Doherty v. Schipper \& Block, 250 III. 128, 95 N.E. 74 (1911); Richardson v. The Eagle Machine Works, 78 Ind. 422 (1\$S1); James v. Board of Cummissioners of Allen County, 4 Ohio St. 226, 6 N.E. 246 (1886); Jameson v. Bard of Education, 78 W. Va 612, 89 S.E. 255 (1916). But see Werner v. Werner, 169 App. Div. 9, 154 N.Y. Supp. 570 (1st Dep't 1915).

187. This will often occur where the employee hopes to regain his job. He may be in immediate need of funds. Or he may desire to test the validity of the disclarge without accepting the repudiation.

188. See cases cited note IS6 supra.

189. See, e.g., Darst v. Míathieson Alkali Works, 81 Fed. 234, 287 (C.C.IV.D. Va. 1896); Van Winkle v. Saterfield, 58 Ark. 617, 622, 25 S.IW. 1113, 1114 (1894). See also Clark, Code Pleading 472-9 (2d ed. 1947). 
nation date; $;^{190}$ otherwise, the statute will bar recovery. But if he sues prior to the termination date, no recovery will be allowed for damages to be incurred subsequent to the trial date; and both the statute of limitations and res judicata will prevent commencing a later suit. ${ }^{101}$ Elimination of this dilemma is required.

Despite their disagreement over the label to be applied to an anticipatory repudiation of an employment contract, all courts agree on the formula for computing whatever damages are granted. An injured employee may recover the contract price (salary) for the period being sued upon less any amount he might reasonably earn during that part of the period left free by the repudiation. ${ }^{192}$ Any expenses saved must also be deducted..$^{103}$ The employee, of course, has the option to rescind the entire contract and recover the reasonable value of services already rendered. ${ }^{104}$ An injured employer may recover the difference between the contract price and what he must pay a similar employee. ${ }^{105}$

\section{LeAse Contracts}

Where a lease is treated as outside the purview of the executory limitation, the injured lessor ${ }^{196}$ may rescind, ${ }^{107}$ or sue immediately for damages, or await

190. See, e.g., Taylor v. Tulsa Tribune Co., 136 F.2d 981 (10th Cir. 1943); sec Granow v. Adler, 24 Ariz. 53, 57, 206 Pac. 590, 593 (1922); Wood v. Girot, 102 Cal. App. 160, 163, 282 Pac. 981, 983 (1929); Lichtenstein v. Brooks, 75 Tex. 196, 198, 12 S.W. 975 (1899).

191. Plaintiff will have split his cause of action; therefore, the first recovery will be a bar to his second action. See cases cited note 186 supra. Also, the statute of limitations will have run, since his cause of action accrued as of the initial breach. See cases cited note 190 supra.

192. See cases cited notes $175,179,182$, and 183 supra.

However, in the few jurisdictions in which the injured employee is permitted to stay idle and sue only when installments are due, he may recover the full salary. S. Blumenthal \& Co. v. Bridges, 91 Ark. 212, 120 S.W. 974 (1909) ; Moore v. Kelley \& Jones Co., 111 Ga. 371, 36 S.E. 802 (1900) ; Allen v. Colliery Engineers' Co., 196 Pa. 512, 46 Atl. 899 (1900); Sistare v. People's Supply Co., 87 S.C. 171, 69 S.E. 152 (1910). This "constructive service" doctrine is rapidly losing the little support it had. See, c.g., OgdenHoward Co. v. Brand, 30 Del. (7 Boyce) 482, 485, 108 Atl. 277, 279 (1919) ; Doherty v. Schipper \& Block, 250 Ill. 128, 95 N.E. 74, 75 (1911).

193. See, e.g., School District of Omaha v. McDonald, 68 Neb. 610, 94 N.W. 829 (1903); Dunn v. Allen, 55 App. Div. 637, 67 N.Y. Supp. 218 (4th Dep't 1900).

194. See, e.g., Kimes v. Davidson Inv. Co., 101 Cal. App. 382, 281 Pac. 639 (1929); Clark v. Manchester, 51 N.H. 594 (1872); Tipple v. Tipple, 189 App. Div. 28, 177 N.Y. Supp. 813 (3d Dep't 1919) semble.

195. See, e.g., Brown v. Cowles, 72 Neb. 896, 101 N.W. 1020 (1904); Silbert v. Katz, 151 N.Y. Supp. 510 (App. Term, 1st Dep't 1915).

196. This comment will not discuss the remedies of an injured lessee upon a repudiation by his lessor. The lessee may, if he fulfills the jurisdiction's statutory requirements, sue for possession. See, generally, 2 Powell, Rent Property $\$ 227$ (1950). Or the lessee may sue for damages computed on the difference between the rent agreed upon and the actual rental value at the time of repudiation. See, e.g., Rainwater v. McGrew, 181 S.W.2d 103 (Tex. Civ. App. 1944).

197. To rescind, the lessor need only accept the surrender of the premises. However, this rule leads to difficulties for the lessor who does not wish to rescind but who desires 
the performance date. ${ }^{198}$ Courts often hold that a lease is an executory bilateral contract by finding that the lessor has impliedly promised to protect the lessee's quiet enjoyment. ${ }^{199}$ Therefore, the lease is not within the executory limitation. Another method used is to label the repudiation plus the failure to pay one installment a present material breach of the lease. ${ }^{200}$ In such cases, the lessor may recover the difference between the lease price and the present rental value in an immediate action. ${ }^{201}$ Thus, mitigation through rerental is required. ${ }^{202}$ But if the lessor refuses to accept the repudiation, while there is scattered holding to the contrary, ${ }^{203}$ he is usually under no duty to mitigate. ${ }^{204}$ The lessor then cannot sue for any installment until it is due. ${ }^{05}$

to mitigate by reletting; reletting, even if verbally for the benefit of the repudiator, may be considered an acceptance of the surrender. See, e.g., Gray v. Kaufman Dairy \& Ice Cream Co., 162 N.Y. 388, 56 N.E. 903 (1900). Some courts hold that reletting creates only a presumption of recission; this may be rebutted by evidence that the lessor notificd the lessee that he was not thereby accepting the surrender. See, c.g., Underhill v. Collins, 132 N.Y. 269,30 N.E. 576 (1892). Still others treat the reletting as only one evidentiary fact to be considered. See, e.g., McGrath v. Shalett, 114 Conn. 622, 159 Atl. 633 (1932).

198. Hawkinson v. Johnston, 122 F.2d 724 (Sth Cir.), cert. denicd, 314 U.S. 694 (1941) ; In re Millings Clothing Co., 238 Fed. 58 (2d Cir.), cert. denicd, 243 U.S. 635 (1916); Leo v. Pearce Stores Co., 54 F.2d 92 (ED. Mich. 1931), damages computed, 57 F.2d 340 (E.D. Mich. 1932) ; Shea v. Leonis, 29 Cal. App. 2d 184, 84 P.2d 277 (1938); Sagamore Corp. v. Willcutt, 120 Conn. 315, 180 Atl. 464 (1935); Williams v. Aeroland Oil Co., 155 Fla. 114, 20 So. 2d 346 (1944) ; Benson v. Iowa Bake-Rite Co., 207 Iowa 410, 221 N.W. 464 (1928) ; Brown v. Cairns, 63 Kan. 584, 66 Pac. 639 (1901); Minneapolis Baseball Co. v. City Bank, 74 Minn. 98, 76 N.W. 1024 (1898); Godfrey v. City of Beatrice, 51 Neb. 272, 70 N.W. 914 (1S97); South MIain Akron v. Lymn Realty, 106 N.E.2d 325 (Ohio Ct. App. 1951) ; Conner v. Warner, 52 Okla. 630, 152 Pac. 1116 (1915); Early v. Isaacson, 31 S.W.2d 515 (Tex. Civ. App. 1930); California Bldg. Co. v. Drury, 103 Wash. 577, $175 \mathrm{Pac} .302$ (1918).

199. See, e.g., Hawhinson v. Johnston, 122 F.2d 724 (Sth Cir.), cert. denied, 314 U.S. 694 (1941); South Main Akron v. Lynn Realty, 105 N.E.2d 325 (Ohio Ct. App. 1951).

200. See, e.g., In re Edgewood Park Junior College, 123 Conn. 74, 192 Atl. 561 (1937).

201. Hawkinson v. Johnston, 122 F.2d 724 (Sth Cir.), cert. denied, 314 U.S. 694 (1941); In re Mullings Clothing Co., 238 Fed. 58 (2d Cir.), cert. denied, 243 U.S. 635 (1916); Leo v. Pearce Stores Co., 57 F.2d 340 (E.D. Mich. 1932); Shea v. Leonis, 29 Cal. App. 2d 184, 84 P.2d 277 (1938) ; Hinde v. Madansky, 161 Ill. App. 216 (1911); Brown v. Cairns, 63 Kan. 584, 66 Pac. 639 (1901); Mrinneapolis Baseball Co. v. City Banl, 74 MIinn. 98, 76 N.W. 1024 (1898) ; Míerrill v. Willis, 51 Neb. 162, 70 N.W. 914 (1897); Armijo v. Pettit, 32 N.M. 469, 259 Pac. 620 (1927) ; Ralph v. Deily, 293 Pa. 90, 141 Atl. 640 (1928) ; Early v. Isaacson, 31 S.W.2d 515 (Tex. Civ. App. 1930) ; Brown v. Hayes, 92 Wash. 300, 159 Pac. 89 (1916). Cf. Palmer v. Connecticut Ry., 311 U.S. 544 (1941) (999 year lease repudiated; only 11 years damages allowed since remainder too speculative).

202. The lessor's damages are computed as if he had relet the premises.

203. Walsh v. Shinner, 20 F.2d 586 (3d Cir. 1927) ; Leo v. Pearce Stores Co., 57 F.2d 340 (E.D. Mich. 1932) ; Hinde v. Mfadansky, 161 Ill. App. 216 (1911); Benson v. Iova Bake-Rite Co., 207 Iowa 410, 221 N.W. 464 (1928); Lips v. Opp, 150 Kan. 745, 96 P.2d 865 (1939).

204. In re Mullings Clothing Co., 252 Fed. 657 (D. Conn. 1918); Rice v. Dudley; 65 Ala. 68 (1880); Browne v. Dugan, 189 Ark. 551, 74 S.W.2d 640 (1934); Shea v. Leonis, 
A substantial number of courts deny an action for anticipatory repudiation of a lease. ${ }^{206}$ Some of these courts view a lease as only a unilateral promise to pay money and therefore within the executory limitation. ${ }^{207}$ Others reject the anticipatory repudiation doctrine because they find, not an absolute promise to pay rent, but a promise that is contingent on possession. ${ }^{208}$ This disregards the fact that the lessee promises to pay for possession whether or not he occupies the premises. And furthermore, in the same case, courts have permitted an action for anticipatory repudiation of a promise to purchase or renovate the leased premises. ${ }^{200}$ No objection is then raised that these promises are contingent upon possession.

Mitigation by rerental should be required of a lessor after repucliation by the lessee. In no other contract can the injured party increase his damages by wasting available property freed by the repudiation. And in no other contract is it more certain that a party will not later withdraw his repudiation. For one who abandons premises does not often return.

\section{CONCLUSION}

Strict freedom of contract, with few exceptions, has regulated the development of the anticipatory repudiation doctrine. Once parties contract, neither

29 Cal. App. 2d 184, 84 P.2d 277 (1938) ; McGrath v. Shalett, 114 Conn. 622, 159 Atl. 633 (1932) ; Williams v. Aeroland Oil Co., 155 Fla. 114, 20 So. $2 d 346$ (1944); Jordon v. Nicleell, 253 S.W.2d 237 (Ky. Ct. App. 1952) ; Lirette v. Sharp, 44 So. 2d 221 (La. App. 1950) ; Merrill v. Willis, 51 Neb. 162, 70 N.W. 914 (1897) ; Zucker v. Dehm, 128 N.J.L. 435, 26 A.2d 564 (1942) ; Becar v. Flues, 64 N.Y. 518 (1876) ; Milling v. Becker, 96 Pa. 182 (1880) ; Goldman v. Broyles, 141 S.W. 283 (Tex. Civ. App. 1911); Crowder v. Virginia Bank, 127 Va. 299 , 103 S.E. 578 (1.920).

205. See, e.g., Williams v. Aeroland Oil Co., supra note 204, Jordon v. Nickell, supra note 204 .

206. First National Bank of Chicago v. First National Bank of Wheaton, 78 F.2d 502 (7th Cir.), cert. denied, 296 U.S. 651 (1935); In re Marshall's Garage, 63 F.2d 750 (2d Cir. 1933); In re McAllister-Mohler Co., 46 F.2d 91 (S.D. Ohio 1930); Rice v. Dudley, 65 Ala. 68 (1880) ; Cerrute v. Burdeck, 130 Conn. 284, 33 A.2d 333 (1943); People v. West Town State Bank, 373 Ill. 106, 25 N.E.2d 509 (1940) ; Jordon v. Nickell, 253 S.W.2d 237 (Ky. Ct. App. 1952) ; Cooper v. Casco Mercantile Trust Co., 134 Me. 372, 186 Atl. 885 (1936) ; Leon v. Barnsdall Zinc Co., 309 Mo. 276, 274 S.W. 699 (1925) ; Willis v. Kronendonk, 58 Utah 592, 200 Pac. 1025 (1921) ; cf. Hermitage Co. v. Levine, 248 N.X. 333, 162 N.E. 97 (1928). See Giesy v. American National Bank of Portland, 31 F. Supp. 524, 525 (D. Ore. 1940); In re Barton Co., 34 F.2d 517, 518 (D.N.H. 1929). Since the lessor may sue only for the rent as due, no mitigation is required here. Jordon v. Nickell, supra.

207. First National Bank of Chicago v. First National Bank of Wheaton, supra note 206; Cerrute v. Burdick, supra note 206; Kroch v. B.G. Operating Co., 286 Ill. App. 301, 3 N.E.2d 285 (1936) (alternate holding) ; Jordon v. Nickell, supra note 206; Leon v. Barnsdall Zinc Co., stipra note 206.

208. In re Marshail's Garage, 63 F.2d 759 (2d Cir. 1933); In re McAllister-Mohler Co., 46 F.2d 91 (S.D. Ohio 1930) ; Calechman v. Great Atlantic \& Pacific Tea Co., 120 Conn. 265, 180 Atl. 450 (1935); Cooper v. Casco Mercantile Trust Co., 134 Me. 372, 186 Atl. 885 (1936) ; cf. People v. West Town State Bank, 373 I1l. 106, 25 N.E.2d 509 (1940).

209. See In re Marshall's Garage, supra note 208; In re Barton Co., 34 F.2d 517 (D. N.H. 1929). 
party can alter the contract unless the other consents. ${ }^{210}$ The non-repudiating party may agree to the repudiation; but until he does, the contract still exists, despite the fact that the injured party would be fully compensated if he immediately accepted the repudiation. Furthermore, confusion over when to compute damages has resulted from the doctrine's development. Since words of repudiation cannot alter a contract, freedom of contract requires computation of damages only at the agreed-upon performance date. ${ }^{211}$ Yet acceptance of the repudiation could be interpreted as an agreement to change the damage computation date. And the ever-present duty to mitigate increases the possible alternatives.

In order to dispel this miasma of confusion, the anticipatory repudiation doctrine should be based on two policies: 1) a contracting party's right to adequate assurance of performance (security) ; and 2) the injured party's right to full compensation, but no more than full compensation.

Security and adequate compensation can both be achieved only by altering the anticipatory repudiation doctrine.212 Upon repudiation, all contractual duties should be discharged, leaving the parties to their legal remedies. And damages should be computed as of the date of repudiation.

The proposed treatment of an anticipatory repudiation will give the injured party complete security. ${ }^{213}$ If plaintiff were required to treat repudiation as a present breach, he could recontract with someone he believes would fulfill the contract. He has no such assurance when he retains a contractual relationship with a repudiator; he is certain only of a future law suit.

210. See, e.g., Callan v. Andrews, 48 F.2d 118 (2d Cir. 1931) ; MrcAllister v. Safeley, 65 Iowa 719, 23 N.W. 139 (1885).

211. See, e.g., John Dimon Corp. v. Federal Sugar Refinery Co., 215 App. Div. 140, 213 N.Y. Supp. 106 (1st Dep't 1925).

212. Cf. I1linois Central R.R. v. Crail, 281 U.S. 57, 64 (1930): "we perceive no advantage to be gained from an adherence to a rigid uniformity, which would justify sacrificing the reason of the rule, to its letter .... It may be discarded and other more accurate means resorted to...."

213. The right to this sense of security is recognized as a reason for contracting. See Roehm v. Horst, 178 U.S. 1, 19 (1900); Hawkinson v. Johnston, 122 F.2d 724, 729 (8th Cir.), cert. denied, 314 U.S. 694 (1941); UCC \$2-609, comment 1; Llewellyn, V'hat Price Contract?, 40 Y AIE L.J. 704, 727 (1931).

The lack of security under present case law is especially apparent where the repudiation is caused by the bankruptcy of one party. Some courts hold that petitioning a contracting party into bankruptcy is sufficient to prove repudiation. MLuehlstein \& Co. v. Hickman, 26 F.2d 40 (Sth Cir. 1928). Others hold that a repudiation occurs only when the trustee or receiver disaffirms the contract. Pennsylvania Steel Co. v. New York Ry., 198 Fed. 721, 735 (2d Cir. 1912). Until the trustee decides, the injured party must remain ready to parform. Samuels v. E. F. Drew \& Co., 286 Fed. 278 (S.D.N.Y. 1922), off'd, 292 Fcd. 734 (2d Cir. 1923). If Bankruptcy Act $\S 70 b, 30$ STAT. 565, as amended, 11 U.S.C. $\$ 110(b)$ (Supp. 1952), is applicable, the trustee must decide within sisty days or the contract is held disaffirmed. Otherwise, if the decision is not made within a reasonable time, the court can order that the choice be made. Ibid. But if the trustee disaffirms the contract, the repudiation is held to have occurred at the date the petition in bankruptcy was filed. And though the injured party could not have recontracted at that time since he had to remain ready to per- 
And the injured party will obtain full compensation. ${ }^{214}$ His recovery will be the difference between the contract price and recontract price following repudiation. The injured party will thus receive performance of the same promises for which he contracted, and for the same consideration. ${ }^{215}$

If the injured party is fully compensated, he can raise no objection to this suggested modification of the anticipatory repudiation doctrine. Of course he is thus held to have recontracted at a time prior to the performance clate despite the fact that he never expressly accepted this duty. But injured parties in all breaches of contract are held to duties for which they never contracted. For example, a buyer does not contract for the duty to find a new seller upon a present breach. Yet the law, in order to minimize the loss, computes damages as if he had done so. ${ }^{216}$

Nor can defendant object to a rule which treats his repudiation as a present breach. He is only being taken at his word. ${ }^{217}$ After all, the repudiating party has the real option. He can silently await the performance date and then cause a present breach. Or he can announce his repudiation prior to the performance date. Many factors may influence his choice. But once it is made, it should be accepted.

To avoid evidentiary problems of proving a repudiation, 218 Section 2-609 of the Uniform Commercial Code should be used. It will also give the injured party an opportunity to convince the repudiator to continue the contract. 210

form, his damages are computed as of that date. In re Portage Rubbor Co., 296 Fed. 289 (6th Cir.), cert. denied, 266 U.S. 604 (1924). For only claims accrued on the date of the petition in bankruptcy may be brought against the bankrupt's estate. Bankruptcy Act $\S 63$, 30 Stat. 562 (1898), as amended, 11 U.S.C. $\$ 103$ (Supp. 1952). Furthermore, if for some reason the jurisdiction does not permit an action for anticipatory repudiation of the contract involved, the innocent party gets no remedy whatsoevèr. First National Bank of Chicago v. First National Bank of Wheaton, 78 F.2d 502 (7th Cir. 1935), cert. denicd, 296 U.S. 651 (1935).

214. "Full compensation" has always been considered the correct measure of damages. See, e.g., Weed v. Lyons Petroleum Co., 294 Fed. 725 (D. Del. 1923), aff'd, 300 Fed. 1005 (3d Cir. 1924) ; Kingman \& Co. v. Western Manufacturing Co., 92 Fed. 486 (8th Cir. 1899); Baessetti v. Shenango Furnace Co., 122 Minn. 335, 142 N.W. 322 (1913).

215. See, e.g., L. Hand, J., in New York Trust Co. v. Island Oil \& Transportation Corp., 34 F.2d 653, 654 (2d Cir. 1929) : "Damages never do more than restore the injured party to the position he would have been in, had the promisor performed . ..." See also Rochm v. Horst, 178 U.S. 1 (1900).

216. See 5 Corrin, Contracts $\S 1039$ (1951).

217. See Hochster v. De 1a Tour, 2 E. \& B. 678, 690 (1853): "It scems strange that the defendant, after renouncing the contract, and absolutely declaring that he will never act under it, should be permitted to object that faith is given to his assertion, and that an apportunity is not left to him of changing his mind." For similar statements, see Roehm v. Horst, 178 U.S. 1, 19 (1900) ; Equitable Trust Co. v. Western Pacific Ry., 244 Fed. 485, 504 (S.D.N.Y. 1917), aff'd, 250 Fed. 327 (2d Cir. 1918).

218. See the discussion of this evidentiary problem in note 7 supra.

219. See note 89 supra for an illustration of the problem faced, under present case law, by a contracting party who attempts to convince his repudiator to continue performance: by such action he might be held to have repudiated the contract. 
Plaintiff, if he is not certain of the defendant's absolute repudiation, ${ }^{200}$ could thereby request adequate assurance of performance. If such assurance is not forthcoming within a reasonable time, the plaintiff would be required to mitigate. And damages would be computed as of that date.

Only one exception to the rule of immediate damage computation must be retained. If the repudiator prevents mitigation by the injured party, damages should not be computed until the latter is able to mitigate. Thus, a buyer may pay for goods in advance. If seller repudiates, but refuses to refund the purchase money, buyer should not be compelled to expend new funds for the same purchase. He should be permitted to do so, and have damages computed on that repurchase. But a duty to mitigate should arise only when the money is refunded. ${ }^{221}$

Undoubtedly, revision of the anticipatory repudiation doctrine will be opposed on the ground that it will serve as an incentive to repudiation. .20 For the repudiator will thereby avoid further risks in a fluctuating market. But so long as the injured party can find someone to incur subsequent market risks, no harm is done. And, while this may give unearned security to an unscrupulous repudiator, most repudiations are not made in bad faith. ${ }^{203}$ The overwhelming number occur because a responsible businessman has made a mistake, or changed his plans. He should be permitted to avoid an undesirable obligation with a minimum of damages. Furthermore, an injured party will almost always prefer to receive advance notice of a refusal to perform ; 294 this gives him time to recontract with someone who will perform.

Immediate computation of damages will add both certainty and justice to this confused field of law.

220. Or if he desires to attempt to convince the repudiator to complete performance.

221. See, e.g., West v. Pritchard, 19 Conn. 212 (1848). Cf. Perkins v. MFinford, 235 N.Y. 301,139 N.E. 276 (1923).

222. See, e.g., Fahey v. Updike Elevator Co., 102 Neb. 249, 252, 165 N.W. 62, 623 (1918) ; Continental Grain Co. v. Simpson Feed Co., 102 F. Supp. 354 (E.D. Ark 1951), modified on other grounds, 199 F.2d 284 (Sth Cir. 1952).

223. See, e.g., Robson \& Evans v. J.R. Hale \& Sons, 139 Ga. 753, 78 S.E. 177 (1913) (buyer repudiates when market price of similar contract higher than contract price). See also Holares, Collected Legal Papers 167 (1920); Holsies, The Courasox Law 300 (1881). Contra: Lagerloef Trading Co. v. American Paper Products Co., 291 Fed. 947 (7th Cir.), cert. desied, 263 U.S. 706 (1923).

224. See, e.g., Hawkinson v. Johnston, 122 F.2d 724, $729-30$ (8th Cir.), cert. dericd, 314 U.S. 694 (1941): "The real sanctity of any contract rests only in the mutual willingness of the parties to perform. Where this willingness ceases to exist, any attempt to prolong or preserve the status between them will usually be unsatisfactory and mechanieal. Generally speaking, it is far better in such a situation, for the individuals and for socicty, that the rights and obligations between them should be promptly and definitely settled .... The commercial world has long since learned the desirability of fixing its liabilities and losses as quickly as possible, and the law similarly needs to remind itself that, to be useful, it too must seek to be practical." See also UCC $\$ 2-609$, comment 1 . 